Article

\title{
The Tyranny of Arm-Wrestling Methyls on Iron(II) Spin State in Pseudo-Octahedral [Fe(didentate) ${ }_{3}$ ] Complexes ${ }^{\dagger}$
}

\author{
Neel Deorukhkar ${ }^{1}$, Timothée Lathion ${ }^{1}$, Laure Guénée ${ }^{2}$, Céline Besnard ${ }^{2}$ and Claude Piguet ${ }^{1, *}$ \\ 1 Department of Inorganic and Analytical Chemistry, University of Geneva, 30 quai E. Ansermet, \\ CH-1211 Geneva 4, Switzerland; Neel.deorukhkar@unige.ch (N.D.); timothee.lathion@gmail.com (T.L.) \\ 2 Laboratory of Crystallography, University of Geneva, 24 quai E. Ansermet, CH-1211 Geneva, 4 Switzerland; \\ Laure.Guenee@unige.ch (L.G.); Celine.Besnard@unige.ch (C.B.) \\ * Correspondence: Claude.Piguet@unige.ch \\ † Dedicated to Dr. Howard Flack (1943-2017).
}

Received: 11 March 2020; Accepted: 31 March 2020; Published: 2 April 2020

\begin{abstract}
The connection of a sterically constrained 3-methyl-pyrazine ring to a $N$-methyl-benzimidazole unit to give the unsymmetrical $\alpha, \alpha^{\prime}$-diimine ligand L5 has been programmed for the design of pseudo-octahedral spin-crossover $\left[\mathrm{Fe}(\mathbf{L} 5)_{3}\right]^{2+}$ units, the transition temperature $\left(T_{1 / 2}\right)$ of which occurs in between those reported for related facial tris-didentate iron chromophores fitted with 3-methyl-pyridine-benzimidazole in a LaFe helicate $\left(T_{1 / 2} \sim 50 \mathrm{~K}\right)$ and with 5-methyl-pyrazine-benzimidazole L2 ligands $\left(T_{1 / 2} \sim 350 \mathrm{~K}\right)$. A thorough crystallographic analysis of $\left[\mathrm{Fe}(\mathbf{L 5})_{3}\right]\left(\mathrm{ClO}_{4}\right)_{2}(\mathrm{I}),\left[\mathrm{Ni}(\mathbf{L 5})_{3}\right]\left(\mathrm{ClO}_{4}\right)_{2}(\mathbf{I I}),\left[\mathrm{Ni}(\mathbf{L} 5)_{3}\right]\left(\mathrm{BF}_{4}\right)_{2} \cdot \mathrm{H}_{2} \mathrm{O}(\mathbf{I I I}),\left[\mathrm{Zn}(\mathbf{L 5})_{3}\right]\left(\mathrm{ClO}_{4}\right)_{2}(\mathbf{I V})$, $\left[\mathrm{Ni}(\mathbf{L} 5)_{3}\right]\left(\mathrm{BF}_{4}\right)_{2} \cdot 1.75 \mathrm{CH}_{3} \mathrm{CN}(\mathbf{V})$, and $\left[\mathrm{Zn}(\mathbf{L 5})_{3}\right]\left(\mathrm{BF}_{4}\right)_{2} \cdot 1.5 \mathrm{CH}_{3} \mathrm{CN}(\mathbf{V I})$ shows the selective formation of pure facial $\left[\mathrm{M}(\mathbf{L} 5)_{3}\right]^{2+}$ cations in the solvated crystals of the tetrafluoroborate salts and alternative meridional isomers in the perchlorate salts. Except for a slightly larger intra-strand interannular twist between the aromatic heterocycles in $\mathbf{L 5}$, the metric parameters measured in $\left[\mathrm{Zn}(\mathbf{L} 5)_{3}\right]^{2+}$ are comparable to those reported for $\left[\mathrm{Zn}(\mathbf{L} 2)_{3}\right]^{2+}$, where $\mathbf{L} 2$ is the related unconstrained ligand. This similitude is reinforced by comparable ligand-field strengths $\left(\Delta_{\text {oct }}\right)$ and nephelauxetic effects (as measured by the Racah parameters $B$ and $C$ ) extracted from the electronic absorption spectra recorded for $\left[\mathrm{Ni}(\mathbf{L} 5)_{3}\right]^{2+}$ and $\left[\mathrm{Ni}(\mathbf{L} 2)_{3}\right]^{2+}$. In this context, the strictly high-spin behavior observed for $\left[\mathrm{Fe}(\mathbf{L} 5)_{3}\right]^{2+}$ within the 5-300 $\mathrm{K}$ range contrasts with the close to room-temperature spin-crossover behavior of $\left[\mathrm{Fe}(\mathbf{L} 2)_{3}\right]^{2+}\left(T_{1 / 2}=349(5) \mathrm{K}\right.$ in acetonitrile). This can be unambiguously assigned to an intraligand arm wrestling match operating in bound L5, which prevents the contraction of the coordination sphere required for accommodating low-spin $\mathrm{Fe}^{\mathrm{II}}$. Since the analogous 3-methyl-pyridine ring in $\left[\mathrm{Fe}(\mathrm{L} 3)_{3}\right]^{2+}$ derivatives are sometimes compatible with spin-crossover properties, the consequences of repulsive intra-strand methyl-methyl interactions are found to be amplified in $\left[\mathrm{Fe}(\mathbf{L})_{3}\right]^{2+}$ because of the much lower basicity of the 3-methyl-pyrazine ring and the resulting weaker thermodynamic compensation. The decrease of the stability constants by five orders of magnitude observed in going from $\left[\mathrm{M}(\mathbf{L} 2)_{3}\right]^{2+}$ to $\left[\mathrm{M}(\mathbf{L} 5)_{3}\right]^{2+}\left(\mathrm{M}=\mathrm{Ni}^{\mathrm{II}}\right.$ and $\left.\mathrm{Zn}^{\mathrm{II}}\right)$ is diagnostic for the operation of this effect, which had been not foreseen by the authors.
\end{abstract}

Keywords: pyrazine-benzimidazole; spin crossover; iron(II); ligand field; nephelauxetic

\section{Introduction}

In line with the formulation of the ligand field theory [1,2], or as it was originally called by Bethe, crystal-field theory [3], it was realized that an open-shell metal with at least two valence electrons in a specific chemical environment could exist with either high-spin or low-spin configuration [4]. 
Following van Vleck's approach to magnetism [5], Pauling perceptively recognized that it would be feasible to obtain systems in which two spin states could be present simultaneously, while their ratio should depend on the energy difference between them [6,7]. The discovery of thermal spin-state equilibria operating in $\mathrm{Fe}^{\mathrm{III}}$ dithiocarbamate by Cambi et al. [8-10] at the same period, indeed confirmed these predictions. Since then, a myriad of metal coordination complexes and polymeric materials have been shown to display spin transitions, often referred to as spin-crossover (SCO) materials. These have been studied in detail and extensively reviewed over the last two decades [11-20]. Due to the 'on-off' switching of the magnetic properties accompanying the spin transition from the low-spin diamagnetic configuration $\left({ }^{1} \mathrm{~A}_{1}\right.$ label in octahedral symmetry) to the high-spin paramagnetic form ( ${ }^{5} \mathrm{~T}_{2}$ label in octahedral symmetry) for $\mathrm{d}^{6}$ transition metals in pseudo-octahedral geometry (Scheme 1a), the 'magic' $\left[\mathrm{Fe}^{\mathrm{II}} \mathrm{N}_{6}\right.$ ] chromophores, where $\mathrm{N}$ is a heterocyclic nitrogen donor atom, have been intensively investigated [11-20]. Various external stimulations such as changes in temperature [21,22], pressure [23,24], magnetic field [25] or light-irradiation [26,27] can be used for inducing the SCO processes, which makes these microscopic magneto-optical switches very attractive for their introduction into responsive macroscopic materials [12,13,16,28-31]. The most common and accepted approach for rationalizing the design of spin-crossover pseudo-octahedral Fe ${ }^{\mathrm{II}}$ complexes relies on the energetic balance $\Delta E_{\mathrm{HL}}=E_{\mathrm{hs}}^{0}-E_{\mathrm{ls}}^{0}=2\left(\Delta_{\mathrm{oct}}-P\right)$ between the ligand-field stabilization energy as measured by $\Delta_{\mathrm{oct}}=10 \mathrm{Dq}$ and the spin pairing energy modeled with the Racah parameters $B$ and $C$ with $P=2 B+4 C \approx 19 B$ (Scheme 1a) [31]. When $\Delta_{\text {oct }}>>P, \Delta E_{\mathrm{HL}}=E_{\mathrm{hs}}^{0}-E_{\mathrm{ls}}^{0}=2\left(\Delta_{\mathrm{oct}}-P\right)>>0$ and the pseudo-octahedral $\mathrm{Fe}^{\mathrm{II}}$ complex adopts a low spin configuration with a diamagnetic ${ }^{1} \mathrm{~A}_{1}$ electronic ground state, as shown in the right part of the Tanabe-Sugano diagram built for the electronic $\mathrm{d}^{6}$ configuration $\left(\Delta_{\text {oct }} / B>20\right.$ in Scheme $\left.1 \mathrm{~b}\right)$. The reverse situation occurs when $P>>\Delta_{\text {oct }}$, which leads to $\Delta E_{\mathrm{HL}}=E_{\mathrm{hs}}^{0}-E_{\mathrm{ls}}^{0}=2\left(\Delta_{\mathrm{oct}}-P\right)<<0$ and the existence of the paramagnetic high-spin ${ }^{5} \mathrm{~T}_{2}$ ground state (left part of Tanabe-Sugano diagram with $\Delta_{\text {oct }} / B<10$ in Scheme 1b). Finally, for intermediate values $0 \leq\left|\Delta E_{\mathrm{HL}}=2\left(\Delta_{\mathrm{oct}}-P\right)\right| \leq m R T(m \leq 10)$, the two spin states coexist and are thermally populated at accessible temperatures. However, the latter statement is misleading and physically unsound since both $\Delta_{\text {oct }}$ and $P$ change during the spin transition as a result of the population of the antibonding orbitals in the high-spin form. For pseudo-octahedral spin-crossover $\left[\mathrm{Fe}^{\mathrm{II}} \mathrm{N}_{6}\right]$ complexes, the Fe-N bond lengths extend by approximately $10 \%$ upon the low-spin to high-spin transition and $\Delta_{\text {oct }}$ consequently decreases according to a $1 / r^{n}$ dependence with $n=5-6$ (Equation (1)) [31].

$$
\frac{\Delta_{\mathrm{oct}}^{\mathrm{HS}}}{\Delta_{\mathrm{oct}}^{\mathrm{LS}}}=\left(\frac{r_{\mathrm{LS}}}{r_{\mathrm{HS}}}\right)^{n}
$$

Taking typical Fe-N bond distances of $r_{\mathrm{LS}}=2.0 \AA$ and $r_{\mathrm{HS}}=2.2 \AA$ [11-20] leads to $\Delta_{\mathrm{oct}}^{\mathrm{LS}} / \Delta_{\mathrm{oct}}^{\mathrm{HS}} \approx$ 1.75 accompanying the spin transition, whereas $P$ changes very little $\left(P^{\mathrm{HS}}: P^{\mathrm{LS}} \cong 19 B\right)$, except for a faint reduction of the nephelauxetic effect with larger bond lengths [32].

Taking into account the $10 \%$ bond length expansion accompanying the spin transition, the simplistic zero-point energy differences between the two states summarized in Scheme 1a (i.e., $\Delta E_{\mathrm{HL}}=E_{\mathrm{hs}}^{0}-E_{\mathrm{ls}}^{0}=$ $2\left(\Delta_{\text {oct }}-P\right)$ ) should be replaced with Equation (2), which is transformed into Equations (3) and (4) upon introducing $\Delta_{\text {oct }}^{\mathrm{LS}} / \Delta_{\text {oct }}^{\mathrm{HS}} \approx 1.75$.

$$
\begin{gathered}
\Delta E_{\mathrm{HL}}=E_{\mathrm{hs}}^{0}-E_{\mathrm{ls}}^{0}=\frac{12}{5} \Delta_{\mathrm{oct}}^{\mathrm{LS}}-\frac{2}{5} \Delta_{\mathrm{oct}}^{\mathrm{HS}}-38 B \\
\Delta E_{\mathrm{HL}}=E_{\mathrm{hs}}^{0}-E_{\mathrm{ls}}^{0}=3.8 \Delta_{\mathrm{oct}}^{\mathrm{HS}}-38 B \\
\Delta E_{\mathrm{HL}}=E_{\mathrm{hs}}^{0}-E_{\mathrm{ls}}^{0}=2.17 \Delta_{\mathrm{oct}}^{\mathrm{LS}}-38 B
\end{gathered}
$$


a) $\quad\left[\mathrm{Fe}^{\mathrm{II}} \mathrm{N}_{6}\right]$

Octahedral (low-spin)

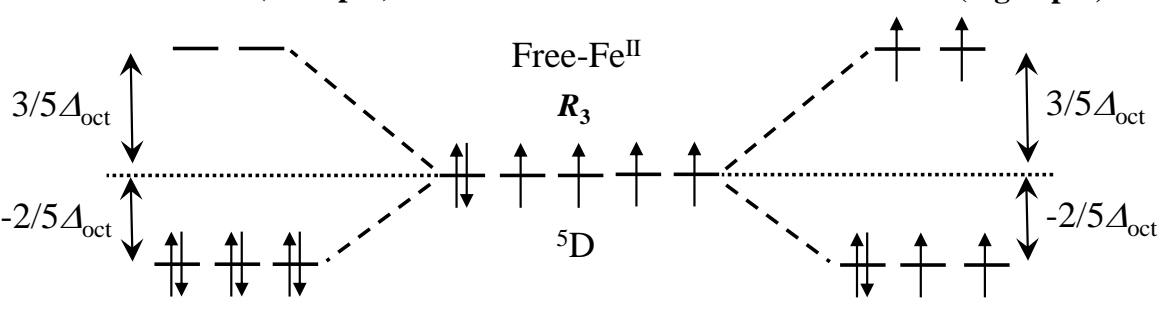

${ }^{1} \mathrm{~A}_{1}$

$$
\begin{aligned}
& \underbrace{E_{\mathrm{ls}}^{0}-E_{R_{3}}=2 P-12 / 5 \Delta_{\mathrm{oct}} \quad E_{\mathrm{hs}}^{0}-E_{R_{3}}=-2 / 5 \Delta_{\mathrm{oct}}} \\
& E_{\mathrm{hs}}^{0}-E_{\mathrm{ls}}^{0}=2\left(\Delta_{\mathrm{oct}}-P\right)
\end{aligned}
$$

b)

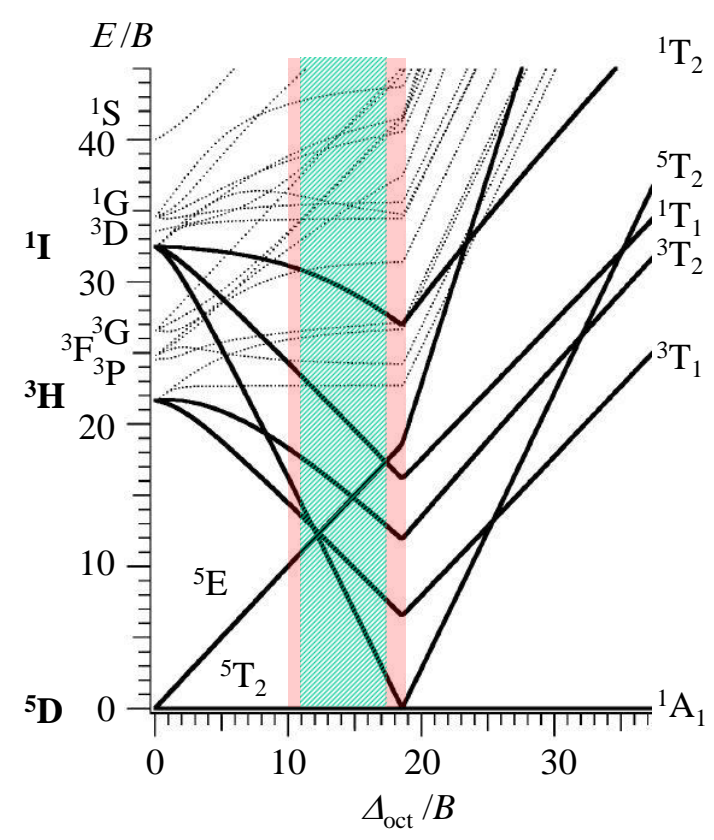

Scheme 1. (a) The thermodynamic origin of $\mathrm{Fe}^{\mathrm{II}}$ spin state equilibrium in octahedral symmetry ( $P$ is the electron spin pairing energy). (b) Tanabe-Sugano diagram for a $\mathrm{d}^{6}$ metal ion calculated using the electrostatic matrices in the strong-field basis and using the free ion Racah parameters $B=917 \mathrm{~cm}^{-1}$ and $C=4.41 \mathrm{~B}=4040 \mathrm{~cm}^{-1}$ [31]. The red areas illustrate the limiting domain of co-existence of low-spin and high-spin complexes for which $0 \leq\left\{E_{\mathrm{hs}}^{0}-E_{\mathrm{ls}}^{0}\right\} \leq 2000 \mathrm{~cm}^{-1}$ with a Racah parameter fixed at $75 \%$ of the free ion values, whereas the dashed green domain corresponds to non-accessible ligand-field strengths (see text) [31].

Solving Equations (3) and (4) for $\Delta E_{\mathrm{HL}}=0$ provides $\Delta_{\mathrm{oct}}^{\mathrm{HS}} / B=38 / 3.8=10$ and $\Delta_{\text {oct }}^{\mathrm{LS}} / B=$ $38 / 2.17=17.5$ as the lower limit of the existence of thermally accessible spin state equilibria, while the higher limits can be estimated for $\Delta E_{\mathrm{HL}}=2000 \mathrm{~cm}^{-1}$, which gives $\Delta_{\mathrm{oct}}^{\mathrm{HS}} / B=10+[2000 /(3.8 B)]$ and $\Delta_{\text {oct }}^{\mathrm{LS}} / B=17.5+[2000 /(2.17 B)]$ (red areas in Scheme 1b). More sophisticated calculations using Racah parameters $B$ and $C$, reduced by $70-80 \%$ of their free ion values, predict narrow ranges of ligand field strengths $11,000 \leq \Delta_{\text {oct }}^{\mathrm{HS}} \leq 12,500 \mathrm{~cm}^{-1}$ and 19,000 $\leq \Delta_{\text {oct }}^{\mathrm{LS}} \leq 22,000 \mathrm{~cm}^{-1}$, for which the phenomenon of a thermal spin transition can be expected in $\mathrm{Fe}^{\mathrm{II}}$ coordination complexes [31]. Following this theoretical approach, the toolkit of coordination chemists for programming and tuning the thermodynamic spin transition parameters in molecular $\left[\mathrm{Fe}^{\mathrm{II}} \mathrm{N}_{6}\right.$ ] complexes logically relied on the manipulation of $\Delta_{\text {oct }}$ and $B$ via (i) some controlled distortions of the coordination geometry from a perfect octahedron 
by using chelating ligands with fixed bite angles [33] and (ii) specific programming of metal-ligand bonding interactions via ligand design $[15,19,34]$. Benefiting from the huge amount of experimental data collected during the last decades for $\left[\mathrm{Fe}\left(\mathrm{N}^{\cap} \mathrm{N}\right)_{3}\right]^{2+}$ complexes, where $\mathrm{N}^{\cap} \mathrm{N}$ is an $\alpha, \alpha^{\prime}$-diimine chelate ligand possessing two N-heterocyclic donor atoms, it was shown that the connection of a six-membered heterocycle to a five-membered heterocycle in $\mathrm{N}^{\cap} \mathrm{N}$ provides favorable ligand-field strengths around $\mathrm{Fe}^{\mathrm{II}}$ for promoting spin-state equilibria (Equation (5)) with transition temperatures $T_{1 / 2}=\Delta H_{\mathrm{SCO}} / \Delta S_{\mathrm{SCO}}$ (i.e., the temperature at which $\Delta G_{\mathrm{SCO}}=0$ and $x_{\mathrm{hs}}=x_{\mathrm{ls}}=0.5$ ) within the $30-500 \mathrm{~K}$ range $[14,15,33]$.

$$
\mathrm{Fe}_{\text {low }- \text { spin }}^{\mathrm{II}} \stackrel{K_{\mathrm{SCO}}}{\rightleftharpoons} \mathrm{Fe}_{\text {high-spin }}^{\mathrm{II}} K_{\mathrm{SCO}}=x_{\mathrm{hs}} / x_{\mathrm{ls}}=e^{-\left(\Delta \mathrm{G}_{\mathrm{SCO}} / R T\right)}=e^{\left(\Delta S_{\mathrm{SCO}} / R-\Delta H_{\mathrm{SCO}} / R T\right)}
$$

The didentate ligands $\mathbf{L} 1$ and $\mathbf{L} 2$ match the latter criteria and the associated pseudo-octahedral complexes $\left[\mathrm{Fe}(\mathbf{L} \boldsymbol{k})_{3}\right]^{2+}$ indeed exhibit spin-crossover behaviors in acetonitrile solutions, the transition temperatures of which reveal the stronger $\mathrm{Fe}-\mathrm{N}$ bonds induced by the strong-accepting pyrazine units in $\left[\mathrm{Fe}(\mathbf{L} 2)_{3}\right]^{2+}\left(T_{1 / 2} \sim 350 \mathrm{~K}\right)$ compared with pyridine units in $\left[\mathrm{Fe}(\mathbf{L} 1)_{3}\right]^{2+}\left(T_{1 / 2} \sim 310 \mathrm{~K}\right.$, Scheme 2$)$ in the absence of sterical constraints [35].
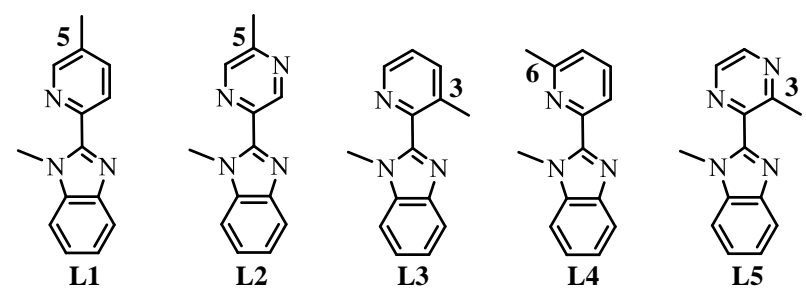

\begin{tabular}{|c|c|c|c|c|c|}
\hline Complex & {$\left[\mathrm{Ni}(\mathbf{L 1})_{3}\right]^{2+}$} & {$\left[\mathrm{Ni}(\mathbf{L 2})_{3}\right]^{2+}$} & {$\left[\mathrm{Ni}(\mathbf{L} 3)_{3}\right]^{2+}$} & {$\left[\mathrm{Ni}(\mathbf{L} 4)_{3}\right]^{2+}$} & {$\left[\mathrm{Ni}(\mathbf{L 5})_{3}\right]^{2+}$} \\
\hline$\Delta_{\mathrm{oct}} / \mathrm{cm}^{-1}$ & 11423 & 11476 & 10681 & 9644 & 11555 \\
\hline$B / \mathrm{cm}^{-1}$ & 889 & 866 & 918 & 994 & 866 \\
\hline$\Delta_{\mathrm{oct}} / B$ & 12.9 & 13.3 & 11.6 & 9.7 & 13.3 \\
\hline Complex & {$\left[\mathrm{Fe}(\mathbf{L 1})_{3}\right]^{2+}$} & {$\left[\mathrm{Fe}(\mathbf{L} 2)_{3}\right]^{2+}$} & {$\left[\mathrm{Fe}(\mathbf{L} 3)_{3}\right]^{2+}$} & {$\left[\mathrm{Fe}(\mathbf{L 4})_{3}\right]^{2+}$} & {$\left[\mathrm{Fe}(\mathbf{L 5})_{3}\right]^{2+}$} \\
\hline$\Delta H_{\mathrm{SCO}} / \mathrm{kJ} \cdot \mathrm{mol}^{-1}$ & $28.3(4)$ & $35.0(3)$ & High-Spin ${ }^{a}$ & High-Spin & High-Spin \\
\hline$\Delta S_{\mathrm{SCO}} / \mathrm{J} \cdot \mathrm{mol}^{-1} \cdot \mathrm{K}^{-1}$ & $91(1)$ & $100(1)$ & High-Spin ${ }^{a}$ & High-Spin & High-Spin \\
\hline$T_{1 / 2} / \mathrm{K}$ & $309(6)$ & $349(5)$ & High-Spin $^{a}$ & High-Spin & High-Spin \\
\hline
\end{tabular}

${ }^{a}$ The $f a c-\left[\mathrm{Fe}(\mathbf{L} 3)_{3}\right]^{5+}$ chromophore, when embedded into a non-constrained LaFe helicate, displayed $T_{1 / 2} \sim 50 \mathrm{~K}$.

Scheme 2. Chemical structures of the didentate ligands L1-L5, together with the electronic properties of the associated pseudo-octahedral $\left[\mathrm{Ni}(\mathbf{L} k)_{3}\right]^{2+}$ complexes and thermodynamic spin-crossover (SCO) properties of the pseudo-octahedral $\left[\mathrm{Fe}(\mathbf{L} \boldsymbol{k})_{3}\right]^{2+}$ complexes in $\mathrm{CD}_{3} \mathrm{CN}$ solutions $[35,36]$.

Moving the methyl group bound to the pyridine ring from the 5-position in $\mathbf{L} 1$ to the 3-position in L3 and to the 6-position in L4 (Scheme 2) is well-known to stepwise decrease the ligand-field strengths in the resulting $\left[\mathrm{Fe}(\mathbf{L} \boldsymbol{k})_{3}\right]^{2+}$ complexes because the operation of additional sterical constraints, produced by intra-strand interactions in $\left[\mathrm{Fe}(\mathbf{L} \mathbf{3})_{3}\right]^{2+}[37]$ and by inter-strand interactions in $\left[\mathrm{Fe}(\mathbf{L} 4)_{3}\right]^{2+}$, extends the Fe-N bond lengths (see Equation (1)) [38-40]. The associated trend $\Delta_{\text {oct }}(\mathbf{L 1}) \approx \Delta_{\text {oct }}(\mathbf{L} 2)>\Delta_{\text {oct }}(\mathbf{L} 3)>$ $\Delta_{\text {oct }}(\mathbf{L} 4)$ observed for the isostructural $\left[\mathrm{Ni}(\mathbf{L} \boldsymbol{k})_{3}\right]^{2+}$ complexes (Scheme 2), for which the determination of ligand field $\Delta_{\text {oct }}$ and Racah $B$ parameters are not complicated by any SCO behavior, are in line with the observation of pure high-spin configurations for the $\left[\mathrm{Fe}(\mathbf{L} 3)_{3}\right]^{2+}$ and $\left[\mathrm{Fe}(\mathbf{L} 4)_{3}\right]^{2+}$ complexes in solution (Scheme 2) [35]. Whereas the connection of methyl groups adjacent to the donor nitrogen atom in the bound 6-methyl-pyridine groups in $\left[\mathrm{Fe}(\mathbf{L} 4)_{3}\right]^{2+}$ produces such large inter-strand interactions that the 
contraction accompanying the high-spin to low-spin transition cannot be envisioned [41], the situation with the remote 3-methyl substituted pyridine units in $\left[\mathrm{Fe}(\mathbf{L} 3)_{3}\right]^{2+}$ is less clear and a sophisticated triple-stranded heterometallic LaFe helicate containing the facial $\left[\mathrm{Fe}(\mathbf{L} 3)_{3}\right]^{2+}$ chromophore has been shown to display partial SCO behavior at low temperature $\left(T_{1 / 2} \sim 50 \mathrm{~K}\right)$ [36]. Taking into account that (i) the replacement of a pyridine with a pyrazine ring in going from $\left[\mathrm{Fe}(\mathbf{L} 1)_{3}\right]^{2+}$ and $\left[\mathrm{Fe}(\mathbf{L} 2)_{3}\right]^{2+}$ stabilizes the low-spin state by $T_{1 / 2}=40 \mathrm{~K}$ (Scheme 2) and (ii) moving the methyl group from the 5-position in $\left[\mathrm{Fe}(\mathbf{L 1})_{3}\right]^{2+}$ to the 3-position in $f a c-\left[\mathrm{Fe}(\mathbf{L} 3)_{3}\right]^{2+}$ (as found in the related LaFe helicate) produces an opposite trend with the stabilization of the high-spin form by $T_{1 / 2} \approx 50-310=-260 \mathrm{~K}$ [36], we thus ingenuously explored the possibility of combining both aspects in the didentate ligand L5 where the methyl group is now connected to the 3-position of a pyrazine ring (Scheme 3a) with the hope of pushing the transition temperature toward cryoscopic temperatures for $\left[\mathrm{Fe}(\mathbf{L} 5)_{3}\right]^{2+}$ around $T_{1 / 2} \sim T_{1 / 2}\left(\left[\mathrm{Fe}(\mathbf{L} 2)_{3}\right]^{2+}\right)-260=350-260=90 \mathrm{~K}$ (3-methyl-pyrazine). This effort is justified by our long-term quest for designing a pseudo-octahedral spin-crossover $\left[\mathrm{Fe}(\mathbf{L} \boldsymbol{k})_{3}\right]^{2+}$ unit that can modulate the luminescence of adjacent emissive lanthanides in (supra)molecular assemblies via energy transfers within a temperature domain $(77-150 \mathrm{~K})$ accessible to optical reading and addressing [36]. Finally, since minor structural variations may induce large changes in ligand-field strength, the systematic exploration of unpredictable intermolecular packing interactions [42,43] operating in crystalline samples of $\left[\mathrm{Fe}(\mathbf{L} 5)_{3}\right] \mathrm{X}_{2}$ complexes $\left(\mathrm{X}^{-}=\right.$monoanionic counter-ions) may contribute to the lucky search for some 'ideal' $\mathrm{Fe}^{\mathrm{II}}$ complexes, which additionally exhibit hysteretic behavior and bistability $[17,44,45]$.

a)

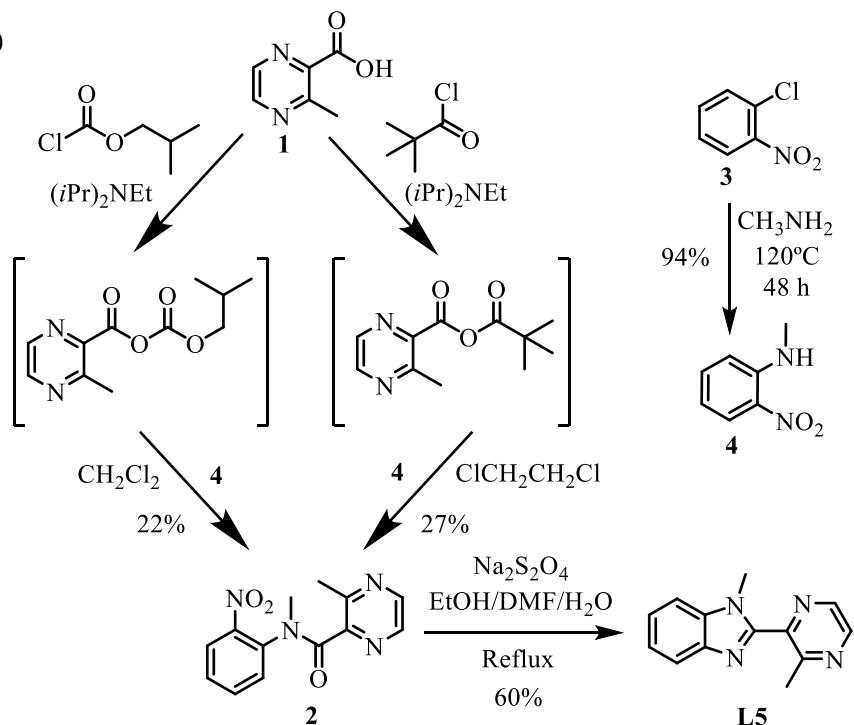

b)

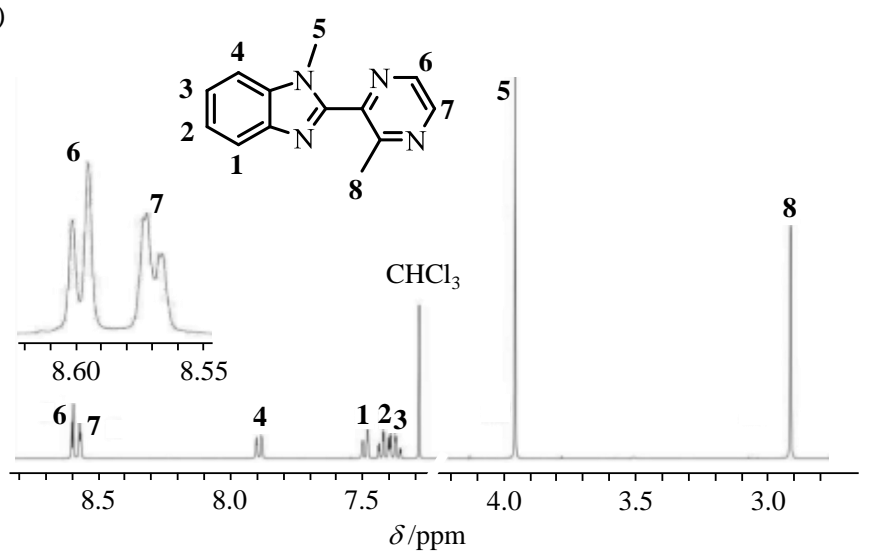

Scheme 3. (a) Chemical structure and synthesis of the didentate ligand $\mathbf{L} 5$ shown in its anti-conformation and (b) associated ${ }^{1} \mathrm{H}$ NMR spectrum with numbering scheme $\left(\mathrm{CDCl}_{3}, 298 \mathrm{~K}\right)$. 


\section{Experimental}

Chemicals were purchased from Sigma-Aldrich (Gmbh, Buchs) and Acros and used without further purification unless otherwise stated. Dichloromethane, 1,2-dichloroethane, tert-butylmethyl ether, and $\mathrm{N}, \mathrm{N}$-dimethylformamide were dried through an alumina cartridge. Silica-gel plates (Merck, $\left.60 \mathrm{~F}_{254}\right)$ were used for thin-layer chromatography, SiliaFlash ${ }^{\circledR}$ silica gel P60 $(0.04-0.063 \mathrm{~mm}$,) and Acros silica gel $60(0.035-0.07 \mathrm{~mm})$ were used for preparative column chromatography.

Preparation of $\mathrm{N}$-methyl-2-nitroaniline (4). 1-chloro-2-nitrobenzene (3, $31.75 \mathrm{~g}, 201.5 \mathrm{mmol}$, 1.0 eq) and methylamine (198 mL, 40\% weight in $\left.\mathrm{H}_{2} \mathrm{O}, 2295.6 \mathrm{mmol}, 11.4 \mathrm{eq}\right)$ were introduced into a Carius tube equipped with a magnetic stirrer and heated at $120^{\circ} \mathrm{C}$ for $48 \mathrm{~h}$. Excess of methylamine was rotatory evaporated and the residual brown oil was partitioned between $\mathrm{CH}_{2} \mathrm{Cl}_{2}(300 \mathrm{~mL})$ and half sat. aq. $\mathrm{NH} 4 \mathrm{Cl}(300 \mathrm{~mL})$. The organic layer was separated and the aq. phase was further extracted with $\mathrm{CH}_{2} \mathrm{Cl}_{2}(3 \times 150 \mathrm{~mL})$. The combined organic extracts were dried over anhydrous $\mathrm{Na}_{2} \mathrm{SO}_{4}$, filtered, and the solvent evaporated to dryness. The resulting red oil was purified by column chromatography (Silica, $\mathrm{CH}_{2} \mathrm{Cl}_{2}$ ) to give $28.99 \mathrm{~g}$ of $\mathrm{N}$-methyl-2-nitroaniline (4, $190.5 \mathrm{mmol}$, yield $94 \%$ ) as a deep red orange oil, which slowly crystallized within hours. ${ }^{1} \mathrm{H} \mathrm{NMR}\left(\mathrm{CDCl}_{3}, 400 \mathrm{MHz}, 298 \mathrm{~K}\right) \delta / \mathrm{ppm:} 8.13$ $\left(1 \mathrm{H}, \mathrm{dd},{ }^{3} J=8.8 \mathrm{~Hz},{ }^{4} J=1.6 \mathrm{~Hz}\right), 8.00(1 \mathrm{H}, \mathrm{bs}), 7.43\left(1 \mathrm{H}, \mathrm{ddd},{ }^{3} J=8.8 \mathrm{~Hz},{ }^{3} J=7.2 \mathrm{~Hz},{ }^{4} J=1.6 \mathrm{~Hz}\right), 6.81$ $\left(1 \mathrm{H}, \mathrm{dd},{ }^{3} J=8.6 \mathrm{~Hz},{ }^{4} J=1.0 \mathrm{~Hz}\right), 6.62\left(1 \mathrm{H}, \mathrm{ddd},{ }^{3} J=8.4 \mathrm{~Hz},{ }^{3} J=7.2 \mathrm{~Hz},{ }^{4} J=1.2 \mathrm{~Hz}\right), 2.99(3 \mathrm{H}, \mathrm{s})$.

Preparation of N,3-dimethyl- $N$-(2-nitrophenyl) pyrazine-2-carboxamide (2, left pathway in Scheme 3a). A suspension of 3-methyl-pyrazine-2-carboxylic acid $(\mathbf{1}, 5 \mathrm{~g}, 35.5 \mathrm{mmol}, 1 \mathrm{eq})$ and di-isopropyl-ethylamine $(7.2 \mathrm{~mL}, 5.5 \mathrm{~g}$, $45 \mathrm{mmol}, 1.26 \mathrm{eq})$ in $\mathrm{CH}_{2} \mathrm{Cl}_{2}(4 \mathrm{~mL})$ was added dropwise into a two-necked flask containing isobutyl chloroformate $(5.4 \mathrm{~mL}, 5.408 \mathrm{~g}, 45 \mathrm{mmol}, 1.26 \mathrm{eq})$ dissolved in $\mathrm{CH}_{2} \mathrm{Cl}_{2}(1 \mathrm{~mL})$. The mixture was stirred at $-15^{\circ} \mathrm{C}$ for $120 \mathrm{~min}$, after which a solution of $\mathrm{N}$-methyl-2-nitroaniline $(4,5.5 \mathrm{~g}, 0.0352 \mathrm{~mol}, 1 \mathrm{eq})$ in $\mathrm{CH}_{2} \mathrm{Cl}_{2}$ was added. After stirring for $15 \mathrm{~h}$ at room temperature, the solution was partitioned between $\mathrm{CH}_{2} \mathrm{Cl}_{2}(100 \mathrm{~mL})$ and half-sat. aq. $\mathrm{NH}_{4} \mathrm{Cl}(250 \mathrm{~mL})$. The organic layer was separated and the aqueous phase was further extracted with $\mathrm{CH}_{2} \mathrm{Cl}_{2}(3 \times 100 \mathrm{~mL})$. The organic fractions were dried over anhydrous $\mathrm{Na}_{2} \mathrm{SO}_{4}$, concentrated under vacuum, and purified by column chromatography (Silica, $\mathrm{CH}_{2} \mathrm{Cl}_{2} / \mathrm{MeOH}$ 99.2:0.8) to yield $\mathrm{N}, 3$-dimethyl- $\mathrm{N}$-(2-nitrophenyl) pyrazine-2-carboxamide (2, $8.22 \mathrm{mmol}$, yield $22 \%) .{ }^{1} \mathrm{H} \mathrm{NMR}\left(\mathrm{CDCl}_{3}, 400 \mathrm{MHz}, 298 \mathrm{~K}\right) \delta / \mathrm{ppm}$ : mixture of two rotamers A $(72.5 \%)$ and B $(27.5 \%): 2.67(3 \mathrm{H}, \mathrm{s}, \mathrm{A}), 2.72(3 \mathrm{H}, \mathrm{s}, \mathrm{B}), 3.58(3 \mathrm{H}, \mathrm{s}, \mathrm{A}), 3.33(3 \mathrm{H}, \mathrm{s}, \mathrm{B})$, 7.37-7.80 (3H, m, A and B), $8.29\left(1 \mathrm{H}, \mathrm{d},{ }^{3} \mathrm{~J}=2.5 \mathrm{~Hz}, \mathrm{~A}\right), 8.60\left(1 \mathrm{H}, \mathrm{d},{ }^{3} \mathrm{~J}=2.5 \mathrm{~Hz}, \mathrm{~B}\right), 8.0\left(1 \mathrm{H}, \mathrm{dd},{ }^{3} \mathrm{~J}=2.5\right.$ $\left.\mathrm{Hz},{ }^{5} J=0.6 \mathrm{~Hz}, \mathrm{~A}\right), 8.50\left(1 \mathrm{H}, \mathrm{dd},{ }^{3} J=2.5 \mathrm{~Hz},{ }^{5} J=0.6 \mathrm{~Hz}, \mathrm{~B}\right), 7.86\left(1 \mathrm{H}, \mathrm{dd},{ }^{3} J=8.5 \mathrm{~Hz},{ }^{4} J=1.5 \mathrm{~Hz}, \mathrm{~A}\right)$, $8.13\left(1 \mathrm{H}, \mathrm{dd},{ }^{3} \mathrm{~J}=8.5 \mathrm{~Hz},{ }^{4} \mathrm{~J}=1.5 \mathrm{~Hz}, \mathrm{~B}\right.$ ). ESI-MS (soft-positive mode; $\left.\mathrm{MeOH}+\mathrm{CHCl}_{3}+\mathrm{HCOOH}\right): \mathrm{m} / \mathrm{z}$ $=273.0\left([2+\mathrm{H}]^{+}\right), 295.1\left([2+\mathrm{Na}]^{+}\right)$.

Preparation of $\mathrm{N}, 3$-dimethyl- $\mathrm{N}$-(2-nitrophenyl) pyrazine-2-carboxamide (2, right pathway in Scheme 3a). A suspension of 3-methyl-pyrazine-2-carboxylic acid (1, $0.2 \mathrm{~g}, 1.44 \mathrm{mmol}, 1 \mathrm{eq})$ and di-isopropyl-ethylamine $(0.37 \mathrm{~mL}, 0.28 \mathrm{~g}, 2.16 \mathrm{mmol}, 1.5 \mathrm{eq})$ in 1,2-dichloroethane $(4 \mathrm{~mL})$ was added dropwise into a two-necked flask containing trimethylacetyl chloride $(0.194 \mathrm{~mL}, 0.19 \mathrm{~g}, 1.58 \mathrm{mmol}, 1.1$ eq) in 1,2-dichloroethane $(1 \mathrm{~mL})$. The mixture was stirred at $-20^{\circ} \mathrm{C}$ for $60 \mathrm{~min}$, after which a solution of $\mathrm{N}$-methyl-2-nitroaniline $(4,0.329 \mathrm{~g}, 2.16 \mathrm{mmol}, 1.5 \mathrm{eq})$ in 1,2-dichloroethane $(5 \mathrm{~mL})$ was added. After refluxing for $16 \mathrm{~h}$, the solution was concentrated under vacuum and partitioned between $\mathrm{CH}_{2} \mathrm{Cl}_{2}(80$ $\mathrm{mL})$ and half-saturated aqueous solution of $\mathrm{NH}_{4} \mathrm{Cl}(200 \mathrm{~mL})$. The organic layer was separated and the aqueous phase was further extracted using $\mathrm{CH}_{2} \mathrm{Cl}_{2}(3 \times 80 \mathrm{~mL})$. The combined organic fractions were concentrated under vacuum after drying with anhydrous $\mathrm{Na}_{2} \mathrm{SO}_{4}$. Ultimate purification using column chromatography (Silica, $\mathrm{CH}_{2} \mathrm{Cl}_{2} / \mathrm{MeOH}$ 99.2:0.8) yielded $0.106 \mathrm{~g}$ of $\mathrm{N}$, 3-dimethyl- $\mathrm{N}$-(2-nitrophenyl) pyrazine-2-carboxamide $(2,0.387 \mathrm{mmol}$, yield $27 \%)$.

Preparation of 1-methyl-2-(3-methylpyrazin-2-yl)-1H-benzo[d]imidazole (L5). $N, 3$-dimethyl- $N$-(2-nitrophenyl)pyrazine-2-carboxamide $(2,2.56 \mathrm{~g}, 7.58 \mathrm{mmol}, 1 \mathrm{eq})$ was dissolved in EtOH:DMF (20 mL:25 mL). Sodium dithionite $(8.0 \mathrm{~g}, 40 \mathrm{mmol}, 5.2 \mathrm{eq})$ was added to the mixture and the temperature of the system was raised to $80^{\circ} \mathrm{C}$ when $20 \mathrm{~mL}$ of water was added. After refluxing for $36 \mathrm{~h}$, the mixture was neutralized using aqueous ammonia and the solvents were removed in vacuo. 
The concentrate was dissolved in $\mathrm{CH}_{2} \mathrm{Cl}_{2}(50 \mathrm{~mL})$ and washed with water $(3 \times 200 \mathrm{~mL})$. The aqueous layers were collectively further extracted with $\mathrm{CH}_{2} \mathrm{Cl}_{2}(3 \times 50 \mathrm{~mL})$. The combined organic fraction was then concentrated under vacuum and purified by column chromatography (silica, $\mathrm{CH}_{2} \mathrm{Cl}_{2} / \mathrm{MeOH}$ 98:2) to yield $\mathbf{L 5}$ (7.67 mmol, yield 60\%). The compound was crystallized as needles by slow diffusion of n-hexane into a concentrated $\mathrm{CH}_{2} \mathrm{Cl}_{2}$ solution of L5. ${ }^{1} \mathrm{H} \mathrm{NMR}\left(\mathrm{CDCl}_{3}, 400 \mathrm{MHz}, 298 \mathrm{~K}\right) \delta / \mathrm{ppm}: 2.91$ $(3 \mathrm{H}, \mathrm{s}), 3.96(3 \mathrm{H}, \mathrm{s}), 7.35-7.44(2 \mathrm{H}, \mathrm{m}), 7.49\left(1 \mathrm{H}, \mathrm{d},{ }^{3} \mathrm{~J}=7 \mathrm{~Hz}\right), 7.88\left(1 \mathrm{H}, \mathrm{d},{ }^{3} J=7 \mathrm{~Hz}\right), 8.57(1 \mathrm{H}-\mathrm{pz}, \mathrm{dd}$, $\left.{ }^{3} J=2.4 \mathrm{~Hz},{ }^{5} J=0.5 \mathrm{~Hz}\right), 8.60\left(1 \mathrm{H}-\mathrm{pz}, \mathrm{dd},{ }^{3} J=2.4 \mathrm{~Hz}\right) .{ }^{13} \mathrm{C} \mathrm{NMR}\left(\mathrm{CDCl}_{3}, 101 \mathrm{MHz}, 298 \mathrm{~K}\right) \delta / \mathrm{ppm}:$ $155.68\left(\mathrm{C}_{\mathrm{q}}\right), 149.12\left(\mathrm{C}_{\mathrm{q}}\right), 144.54\left(\mathrm{C}_{\mathrm{q}}\right), 143.84\left(\mathrm{CH}_{\mathrm{pz}}\right), 142.45\left(\mathrm{C}_{\mathrm{q}}\right), 140.86\left(\mathrm{CH}_{\mathrm{pz}}\right), 136.15\left(\mathrm{C}_{\mathrm{q}}\right), 123.85$ $(\mathrm{CH}), 122.90(\mathrm{CH}), 120.45(\mathrm{CH}), 110.01(\mathrm{CH}), 31.83\left(\mathrm{CH}_{3}\right), 23.26\left(\mathrm{CH}_{3}\right)$. ESI-MS (soft-positive mode; $\left.\mathrm{MeOH}+\mathrm{CHCl}_{3}+\mathrm{HCOOH}\right): m / z 225.1\left([\mathbf{L} 5+\mathrm{H}]^{+}\right)$. Elemental analysis calculated for $\mathrm{C}_{13} \mathrm{H}_{12} \mathrm{~N}_{4}(\%)$ : C 69.62, H 5.39, N 24.98; Found (\%): C 69.46, H 5.09, N 25.20.

Preparation of mononuclear $\mathrm{Fe}^{\mathrm{II}}, \mathrm{Zn}^{\mathrm{II}}$, and $\mathrm{Ni}^{\mathrm{II}}$ complexes with 1-methyl-2-(3-methylpyrazin-2-yl)- $1 H$-benzo[d]imidazole (L5). In a typical synthesis, $0.3 \mathrm{mmol}$ ( 3 eq) of the ligand $\mathbf{L} 5$ dissolved in acetonitrile $\left(2 \mathrm{~mL}\right.$ ) was added to $0.1 \mathrm{mmol}(1 \mathrm{eq})$ of $\mathrm{Fe}\left(\mathrm{ClO}_{4}\right)_{2} \cdot 6 \mathrm{H}_{2} \mathrm{O}$ or $\mathrm{Fe}\left(\mathrm{CF}_{3} \mathrm{SO}_{3}\right)_{2}$ or $\mathrm{Ni}\left(\mathrm{BF}_{4}\right)_{2} \cdot 6 \mathrm{H}_{2} \mathrm{O}$ or $\mathrm{Zn}\left(\mathrm{CF}_{3} \mathrm{SO}_{3}\right)_{2}$ in acetonitrile $(2 \mathrm{~mL})$. The resulting mixture was stirred under an inert atmosphere for $3 \mathrm{~h}$, then evaporated to dryness under vacuum to yield microcrystalline powders of the respective complexes. These powders were dissolved in acetonitrile and allowed to crystallize by evaporation or by slow diffusion of tert-butyl methyl ether to give 64-78\% of primary $\left[\mathrm{Fe}(\mathbf{L} 5)_{3}\right]\left(\mathrm{CF}_{3} \mathrm{SO}_{3}\right)_{2} \cdot 1.5 \mathrm{H}_{2} \mathrm{O},\left[\mathrm{Ni}(\mathbf{L} 5)_{3}\right]\left(\mathrm{BF}_{4}\right)_{2} \cdot 1.5 \mathrm{H}_{2} \mathrm{O} \cdot 1.5 \mathrm{CH}_{3} \mathrm{CN}$ and $\left[\mathrm{Zn}(\mathbf{L} 5)_{3}\right]\left(\mathrm{BF}_{4}\right)_{2} \cdot 4 \mathrm{H}_{2} \mathrm{O}$ complexes (Table S1). Single crystals suitable for characterization by $\mathrm{X}$-ray diffraction could be obtained by slow evaporation of acetonitrile solution containing 10 eq of $\left({ }^{n} \mathrm{Bu}\right)_{4} \mathrm{NClO}_{4}$ or $\left({ }^{n} \mathrm{Bu}\right)_{4} \mathrm{NBF}_{4}$ to give $\left[\mathrm{Fe}(\mathbf{L} 5)_{3}\right]\left(\mathrm{ClO}_{4}\right)_{2}$ (I), $\left[\mathrm{Ni}(\mathbf{L} 5)_{3}\right]\left(\mathrm{ClO}_{4}\right)_{2}$ (II), $\left[\mathrm{Ni}(\mathbf{L} 5)_{3}\right]\left(\mathrm{BF}_{4}\right)_{2} \cdot \mathrm{H}_{2} \mathrm{O}$ (III), $\left[\mathrm{Zn}(\mathbf{L} 5)_{3}\right]\left(\mathrm{ClO}_{4}\right)_{2}$ (IV), $\left[\mathrm{Ni}(\mathbf{L} 5)_{3}\right]\left(\mathrm{BF}_{4}\right)_{2} \cdot 1.75 \mathrm{CH}_{3} \mathrm{CN}(\mathrm{V})$ and $\left[\mathrm{Zn}(\mathrm{L} 5)_{3}\right]\left(\mathrm{BF}_{4}\right)_{2} \cdot 1.5 \mathrm{CH}_{3} \mathrm{CN}(\mathrm{VI})$.

Caution! Dry perchlorates may explode and should be handled in small quantities and with the necessary precautions $[46,47]$.

\subsection{Spectroscopic and Analytical Measurements}

${ }^{1} \mathrm{H}$ and ${ }^{13} \mathrm{C}$ NMR spectra were recorded at $298 \mathrm{~K}$ on a Bruker Avance $400 \mathrm{MHz}$ spectrometer. Chemical shifts are given in ppm with respect to tetramethylsilane. Spectrophotometric titrations were performed with a J\&M diode array spectrometer (Tidas series) connected to an external computer. In a typical experiment, $25 \mathrm{~cm}^{3}$ of ligand in acetonitrile $\left(2 \times 10^{-4} \mathrm{M}\right)$ was titrated at $298 \mathrm{~K}$ with a solution of $\mathrm{Fe}\left(\mathrm{CF}_{3} \mathrm{SO}_{3}\right)_{2}$ or $\mathrm{Ni}\left(\mathrm{BF}_{4}\right) 2 \cdot 6 \mathrm{H}_{2} \mathrm{O}$ or $\mathrm{Zn}\left(\mathrm{CF}_{3} \mathrm{SO}_{3}\right)_{2}\left(2 \times 10^{-3} \mathrm{M}\right)$ in acetonitrile under an inert atmosphere. After each addition of $33 \mu \mathrm{L}$, the absorbance was recorded using Hellma optrodes (optical path length $0.1 \mathrm{~cm}$ ) immersed in the thermostated titration vessel and connected to the spectrometer. Mathematical treatment of the spectrophotometric titrations was performed with factor analysis [48-50] and with ReactLab ${ }^{\mathrm{TM}}$ Equilibria (previously Specfit/32) [51-53]. Pneumatically-assisted electrospray (ESI-MS) mass spectra were recorded from $10^{-4} \mathrm{M}$ (ligands) and $10^{-3} \mathrm{M}$ (complexes) solutions on an Applied Biosystems API 150EX LC/MS System equipped with a Turbo Ionspray source. Elemental analyses were performed by K. L. Buchwalder from the Microchemical Laboratory of the University of Geneva. Elemental analysis was not conducted for perchlorate salts for security reasons, while crystals of the tetrafluoroborate salts lost their solvent upon separation from the mother liquor and were not further characterized. Electronic spectra in the UV-Vis region were recorded at $293 \mathrm{~K}$ from solutions in $\mathrm{CH}_{3} \mathrm{CN}$ with a Perkin-Elmer Lambda 1050 using quartz cells of a 0.1 or $1.0 \mathrm{~mm}$ path length. Solid-state absorption spectra were recorded with a Perkin-Elmer Lambda 900 using capillaries. Solid-state magnetic data were recorded on a MPMS 3 or MPMS 5 QUANTUM DESIGN magnetometers using magnetic fields of $1000-5000$ Oe at $1 \mathrm{~K} / \mathrm{min}$ rates within the 5-300 $\mathrm{K}$ range. The magnetic susceptibilities were corrected for the magnetic response of the sample holder and for the diamagnetism of the compounds by using the approximation $\chi_{\mathrm{D}}=-\frac{\mathrm{MW}}{2} \cdot 10^{-6} \mathrm{~cm}^{3} \cdot \mathrm{mol}^{-1}[54]$. 


\subsection{X-Ray Crystallography}

Summary of crystal data, intensity measurements, and structure refinements for compounds L5, $\left[\mathrm{Fe}(\mathbf{L} 5)_{3}\right]\left(\mathrm{ClO}_{4}\right)_{2}(\mathbf{I}),\left[\mathrm{Ni}(\mathbf{L} 5)_{3}\right]\left(\mathrm{ClO}_{4}\right)_{2}(\mathbf{I I}),\left[\mathrm{Ni}(\mathbf{L 5})_{3}\right]\left(\mathrm{BF}_{4}\right)_{2} \cdot \mathrm{H}_{2} \mathrm{O}(\mathbf{I I I})$, and $\left[\mathrm{Zn}(\mathbf{L 5})_{3}\right]\left(\mathrm{ClO}_{4}\right)_{2}(\mathbf{I V})$ is presented in Tables S2-S4. Pertinent bond lengths, bond angles, and interplanar angles are collected in Tables S5-S14 together with ORTEP views and pertinent numbering schemes gathered in Figures S1-S5. The crystals were mounted on MiTeGen kapton cryoloops with protection oil. X-ray data collection was performed with an Agilent SuperNova Dual diffractometer equipped with a CCD Atlas detector $(\mathrm{Cu}[\mathrm{K} \alpha]$ radiation). The structures were solved by using direct methods $[55,56]$ or dual-space methods [57]. Full-matrix least-square refinements on $F^{2}$ were performed with SHELX2014 [58]. CCDC 1988655-1988659 contained the supplementary crystallographic data. These data can be obtained free of charge from the Cambridge Crystallographic Data Centre via www.ccdc.cam.ac.uk/. Single crystals of $\left[\mathrm{Ni}(\mathbf{L} 5)_{3}\right]\left(\mathrm{BF}_{4}\right)_{2} \cdot 1.75 \mathrm{CH}_{3} \mathrm{CN}(\mathbf{V})$ and $\left[\mathrm{Zn}(\mathbf{L} 5)_{3}\right]\left(\mathrm{BF}_{4}\right)_{2} \cdot 1.5 \mathrm{CH}_{3} \mathrm{CN}(\mathbf{V I})$ could also be obtained as inversion twins. The two complexes were isostructural and crystallized in the trigonal system $(P 3 c 1$ space group) with five independent complexes in the asymmetric unit, all located on three-fold rotation axes (the metal content of the asymmetric unit is 5/3) and $Z=10$ (Table S15). Although there is no doubt that the three ligands adopt facial arrangements around the metal to give exclusively $f a c-\left[M(L 5)_{3}\right]^{2+}$ cations (Figures S6-S7), we were only able to locate unambiguously three $\mathrm{BF}_{4}{ }^{-}$counter-anions in the asymmetric unit. Despite numerous efforts, we were not able to obtain a satisfying model for the last third of a $\mathrm{BF}_{4}{ }^{-}$counter-anion and gave up to further discuss these structures and to deposit the cif files.

\section{Results and Discussion}

Synthesis, characterization, and solid-state structures were obtained for the didentate ligand $\mathbf{L} 5$ and its pseudo-octahedral complexes $\left[\mathrm{M}(\mathbf{L} 5)_{3}\right] \mathrm{X}_{2}\left(\mathrm{M}=\mathrm{Fe}, \mathrm{Ni}, \mathrm{Zn}\right.$ and $\left.\mathrm{X}=\mathrm{BF}_{4}, \mathrm{ClO}_{4}\right)$. Compared with pyridine-carboxylic acids, which are easily activated via their transformation into acyl chloride with the help of thionyl chloride or oxalyl chloride [59], the electron-rich pyrazine analogue $\mathbf{1}$ produced only negligible yield $(<1 \%)$ of the target amide product 2 under these standard conditions [60]. The 3-methylpyrazine-2-carboxylic acid $\mathbf{1}$ was thus activated as its anhydride through reaction with either isobutyl chloroformate (left path in Scheme 3a) or pivaloyl chloride (right path in Scheme 3a). Subsequent nucleophilic attack with $\mathrm{N}$-methyl-2-nitroaniline 4 yielded the ortho-nitroamide compound $\mathbf{2}$ in moderate yield. A subsequent reductive cyclisation reaction provided ligand L5, which was characterized by its ${ }^{1} \mathrm{H}-\mathrm{NMR}$ spectrum (Scheme $3 b$ ). The lack of NOE effect observed between the methyl groups in positions 5 and 8 indicates an anti-conformation for the $\alpha, \alpha^{\prime}$-diimine chelate unit, which was confirmed by (i) the crystal structure of L5 (Figure 1a) and (ii) gas-phase calculations predicting a global energy minimum for the planar anti-conformation (interplanar angle between the two aromatic rings $\alpha=180^{\circ}$, Figure 1b) [61]. Given that the same anti-conformations are (i) found in the solid state (Figure S8) and (ii) predicted in the gas phase for the ligands L2 [60] and L5, their computed EHMO frontiers orbitals are comparable (Figure S9a) and lead to akin electronic absorption spectra dominated by intense $\pi^{*} \leftarrow \pi$ covering the near UV range (Figure S9b). 
a)

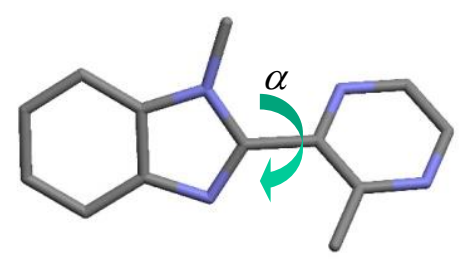

b)

L5

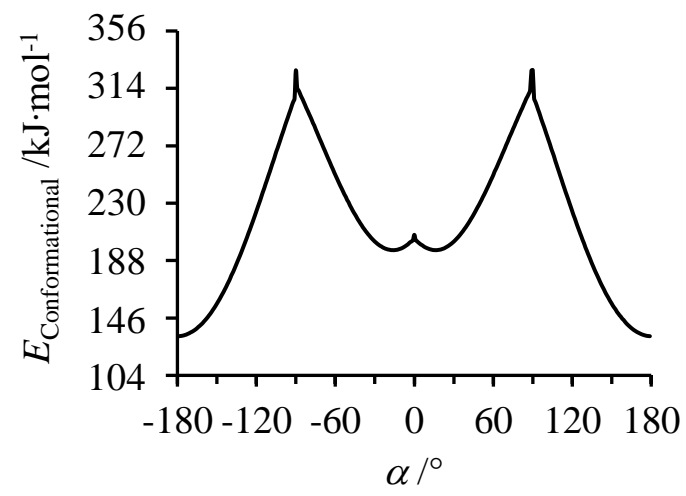

Figure 1. (a) Molecular structure of ligand L5 in its crystal structure highlighting the dihedral angle $\alpha=144.8^{\circ}$ ( $\alpha=180^{\circ}$ for a planar anti-conformation and $\alpha=0^{\circ}$ for a planar syn-conformation). (b)

Gas-phase energy computed for L5 at the MM2 level as a function of the interplanar angle [61].

Interestingly, the gas-phase energy of L5 displayed two additional local energy minima for $\alpha= \pm 16^{\circ}$ (Figure $1 \mathrm{~b}$ ), which shifted from $\alpha=0^{\circ}$ previously reported for the second local minimum in L2 (Figure S10) [60]. The larger interplanar angle of $16^{\circ}$ in the optimized syn-conformation of $\mathbf{L} 5$ was the result of the sterical crowding between the close methyl groups connected to the adjacent aromatic rings (positions 5 and 8 in the numbering of Scheme $3 \mathrm{~b}$ ). Taking the latter conformation as a limiting structural model when $\mathbf{L} 5$ is bound to a metal cation provides $d_{\mathrm{N} \cdots \mathrm{N}}=2.83 \AA$ between the two nitrogen donor atoms of the $\alpha, \alpha^{\prime}$-diimine chelate. According to Phan et al. [33], the latter separation matches the $2.78 \leq d_{\mathrm{N} \cdots \mathrm{N}} \leq 2.93 \AA$ range for which a diimine ligand might be used to achieve spin-crossover behavior in tris-homoleptic $\mathrm{Fe}^{\mathrm{II}}$ complexes.

Stoichiometric mixing of $\mathbf{L} 5$ (3 eq.) with $\mathrm{Fe}\left(\mathrm{CF}_{3} \mathrm{SO}_{3}\right)_{2}, \mathrm{Ni}\left(\mathrm{BF}_{4}\right)_{2} \cdot 6 \mathrm{H}_{2} \mathrm{O}$ or $\mathrm{Zn}\left(\mathrm{BF}_{4}\right)_{2} \cdot 6 \mathrm{H}_{2} \mathrm{O}(1 \mathrm{eq}$, in acetonitrile gave fair yields of microcrystalline primary precipitates of $\left[\mathrm{Fe}(\mathbf{L 5})_{3}\right]\left(\mathrm{CF}_{3} \mathrm{SO}_{3}\right)_{2} \cdot 1.5 \mathrm{H}_{2} \mathrm{O}$, $\left[\mathrm{Ni}(\mathbf{L} 5)_{3}\right]\left(\mathrm{BF}_{4}\right)_{2} \cdot 1.5 \mathrm{H}_{2} \mathrm{O} \cdot 1.5 \mathrm{CH}_{3} \mathrm{CN}$, and $\left[\mathrm{Zn}(\mathbf{L 5})_{3}\right]\left(\mathrm{BF}_{4}\right)_{2} \cdot 4 \mathrm{H}_{2} \mathrm{O}$ complexes (Table S1). A series of isostructural complexes $\left[\mathrm{Fe}(\mathbf{L} 5)_{3}\right]\left(\mathrm{ClO}_{4}\right)_{2}(\mathbf{I}),\left[\mathrm{Ni}(\mathbf{L 5})_{3}\right]\left(\mathrm{ClO}_{4}\right)_{2}(\mathbf{I I})$, and $\left[\mathrm{Zn}(\mathbf{L} 5)_{3}\right]\left(\mathrm{ClO}_{4}\right)_{2}(\mathbf{I V})$ could be obtained as single crystals by recrystallization in acetonitrile containing 10 eq of $\left({ }^{n} \mathrm{Bu}\right)_{4} \mathrm{NClO}_{4}$.

Monocrystals suitable for x-ray diffractions were also obtained for $\left[\mathrm{Ni}(\mathbf{L 5})_{3}\right]\left(\mathrm{BF}_{4}\right)_{2} \cdot \mathrm{H}_{2} \mathrm{O}$ (III), $\left[\mathrm{Ni}(\mathbf{L} 5)_{3}\right]\left(\mathrm{BF}_{4}\right)_{2} \cdot 1.75 \mathrm{CH}_{3} \mathrm{CN}(\mathbf{V})$, and $\left[\mathrm{Zn}(\mathbf{L 5})_{3}\right]\left(\mathrm{BF}_{4}\right)_{2} \cdot 1.5 \mathrm{CH}_{3} \mathrm{CN}(\mathbf{V I})$ using the same method except for the replacement of $\left({ }^{n} \mathrm{Bu}\right)_{4} \mathrm{NClO}_{4}$ with $\left({ }^{n} \mathrm{Bu}\right)_{4} \mathrm{NBF}_{4}$ (Tables S3 and S4). The crystal structures of the perchlorate salts systematically displayed the formation of mer- $\left[\mathrm{M}(\mathrm{L} 5)_{3}\right]^{2+}$ cations (Figure 2), in which the $\left[\mathrm{MN}_{6}\right]$ chromophores adopted a geometry close to the perfect octahedron as ascertained by SHAPE's scores close to zero (Table 1) [62-66]. 

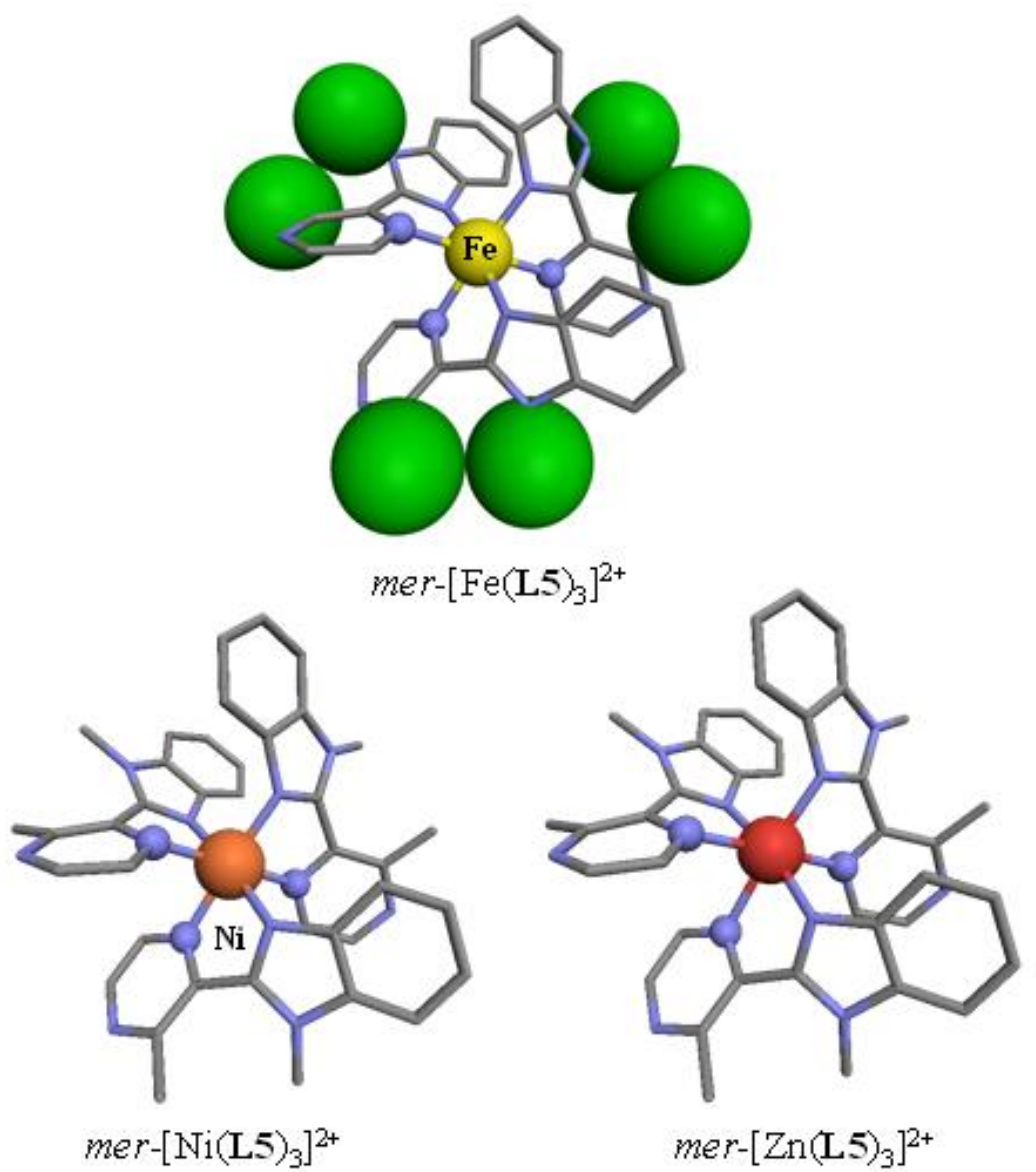

Figure 2. Perspective views of the molecular structures of the $\left[\mathrm{M}(\mathrm{L} 5)_{3}\right]^{2+}$ cations in the crystal structures of $\left[\mathrm{Fe}(\mathbf{L 5})_{3}\right]\left(\mathrm{ClO}_{4}\right)_{2}(\mathbf{I}),\left[\mathrm{Ni}(\mathbf{L 5})_{3}\right]\left(\mathrm{ClO}_{4}\right)_{2}(\mathbf{I I})$, and $\left[\mathrm{Zn}(\mathbf{L} 5)_{3}\right]\left(\mathrm{ClO}_{4}\right)_{2}(\mathbf{I V})$. The nitrogen atoms of the pyrazine rings bound to the metals are displayed with blue spheres in order to highlight their meridional arrangements around the central cation. Color codes: $\mathrm{C}=$ grey, $\mathrm{N}=$ blue. Hydrogen atoms and ionic perchlorate counter-anions are omitted for clarity. For $\left[\mathrm{Fe}(\mathbf{L} 5)_{3}\right]\left(\mathrm{ClO}_{4}\right)_{2}(\mathbf{I})$, the carbon atoms of the methyl groups are shown as green spheres using the Corey-Pauling-Koltun (CPK) model to highlight the intra-strand steric hindrance.

On the contrary, the crystal structures of the tetrafluoroborate salts showed the existence of $f a c-\left[M(L 5)_{3}\right]^{2+}$, in which the three didentate ligands adopted the same orientation along the pseudo-threefold axis passing through the metal (Figure 3). Having previously established that the energy gap between the facial $\left(C_{3}\right.$-symmetry) and meridional $\left(C_{1}\right.$-symmetry) geometries in $\left[\mathrm{Zn}(\mathbf{L 1})_{3}\right]^{2+}$ and $\left[\mathrm{Zn}(\mathbf{L} 2)_{3}\right]^{2+}$ roughly followed a pure statistical (i.e., entropic) trend and does not overcome thermal energy at room temperature [60], we concluded that packing forces, specific to the use of perchlorate or tetrafluoroborate counter anions, are more than enough for the quantitative and selective crystallization of pure meridional, respectively facial isomers. For the $\left[\mathrm{Ni}(\mathbf{L} 5)_{3}\right]^{2+}$ and $\left[\mathrm{Zn}(\mathbf{L})_{3}\right]^{2+}$ chromophores, the $\mathrm{M}-\mathrm{N}$ bonds are systematically shorter for the more basic benzimidazole nitrogen donor (Table 1, entry $\left.4 ; \mathrm{p} K_{\mathrm{a}}(\mathrm{bzim})=5.68\right)$ than with its pyrazine counterpart (Table 1 , entry $5 ; \mathrm{p} K_{\mathrm{a}}($ pyrazine $\left.)=0.65\right)$ [67], a trend in complete agreement with that reported for the analogous complex $\left[\mathrm{Zn}(\mathbf{L} 2)_{3}\right]^{2+}($ Table 1 , column 8) [60]. Moreover, the shift of the methyl group bound to the pyrazine ring from the 5-position in $\mathbf{L} 2$ to the 3-position in $\mathbf{L} 5$ has globally no geometric influence on the $\left[\mathrm{ZnN}_{6}\right]$ coordination sphere, thus leading to $\mathrm{Zn}-\mathrm{N}$ bond distances surrounding the standard value of $\mathrm{Zn}-\mathrm{N}=0.74+1.46=2.20 \AA$ deduced from the effective ionic radii [68]. In other words, the close methyl groups found in the bound didentate ligand $\mathbf{L} 5$ do not induce major intramolecular steric constraints in $\left[\mathrm{Zn}(\mathbf{L} 5)_{3}\right]^{2+}$ and only a slight increase of the interannular intraligand angles can be detected in going from $\left[\mathrm{Zn}(\mathbf{L} 2)_{3}\right]^{2+}(\alpha=$ 
$\left.21(13)^{\circ}\right)$ to $\left[\mathrm{Zn}(\mathbf{L 5})_{3}\right]^{2+}\left(\alpha=38(4)^{\circ}\right.$, entry 5 in Table 1$)$. The molecular structures of $\left[\mathrm{Ni}(\mathbf{L} 5)_{3}\right]^{2+}$ were very similar to those observed for the $\mathrm{Zn}^{\mathrm{II}}$ analogues (Figures 2 and 3), except for the slightly shorter $\mathrm{Ni}-\mathrm{N}$ bond distances, a trend in line with the contraction of Shannon's effective ionic radii predicted to be $0.74 \AA$ for six-coordinate $\mathrm{Zn}^{2+}$ and $0.69 \AA$ for six-coordinate $\mathrm{Ni}^{2+}$ [68]. The detection of long $\mathrm{Fe}-\mathrm{N}$ bond distances in $\left[\mathrm{Fe}(\mathbf{L} 5)_{3}\right]^{2+}\left(d\left(\mathrm{Fe}-\mathrm{N}_{\mathrm{bz}}\right)=2.14(1) \AA\right.$ and $d\left(\mathrm{Fe}-\mathrm{N}_{\mathrm{pz}}\right)=2.24(3) \AA$, entries $3-4$ in Table 1) is more remarkable since it suggests that the $\mathrm{Fe}^{\mathrm{II}}$ metal center adopts a pure high spin configuration at $180 \mathrm{~K}$ as previously found for the analogous 3-methylpyridine-benzimidazole ligand in $\left[\mathrm{Fe}(\mathbf{L} 3)_{3}\right]^{2+}$ $\left(d\left(\mathrm{Fe}-\mathrm{N}_{\mathrm{bz}}\right)=2.14(2) \AA\right.$ and $\left.d\left(\mathrm{Fe}-\mathrm{N}_{\mathrm{py}}\right)=2.26(5) \AA\right)$ [35].

Spin-state, magnetic, and electronic properties of the pseudo-octahedral complexes $\left[\mathrm{M}(\mathrm{L} 5)_{3}\right] \mathrm{X}_{2}$ $\left(\mathrm{M}=\mathrm{Fe}, \mathrm{Ni}\right.$ and $\left.\mathrm{X}=\mathrm{BF}_{4}, \mathrm{ClO}_{4}\right)$ were obtained in the solid state. Molar magnetic susceptibilities $\left(\chi_{\mathrm{M}}\right)$, corrected for diamagnetism of solid state samples of $\left[\mathrm{Fe}(\mathbf{L 5})_{3}\right]\left(\mathrm{ClO}_{4}\right)_{2}$ (I) were recorded at variable temperatures in a constant magnetic field of 5000 Oe. The $\chi_{M} T$ versus $T$ plot shows a smooth and regular increase of the $\chi_{\mathrm{M}} T$ product in the $50-300 \mathrm{~K}$ range (red trace in Figure 4), which can be fitted to Equation (6) using a high Curie constant $C=3.5708(9) \mathrm{cm}^{3} \cdot \mathrm{K} \cdot \mathrm{mol}^{-1}$ and a non-negligible temperature independent paramagnetism TIP $=848(5) \times 10^{-6} \mathrm{~cm}^{3} \cdot \mathrm{mol}^{-1}$, a behavior diagnostic for a high-spin $\mathrm{Fe}(\mathrm{II})$ complex [69].

$$
\chi_{\mathrm{M}} T=C+T \cdot \mathrm{TIP}
$$
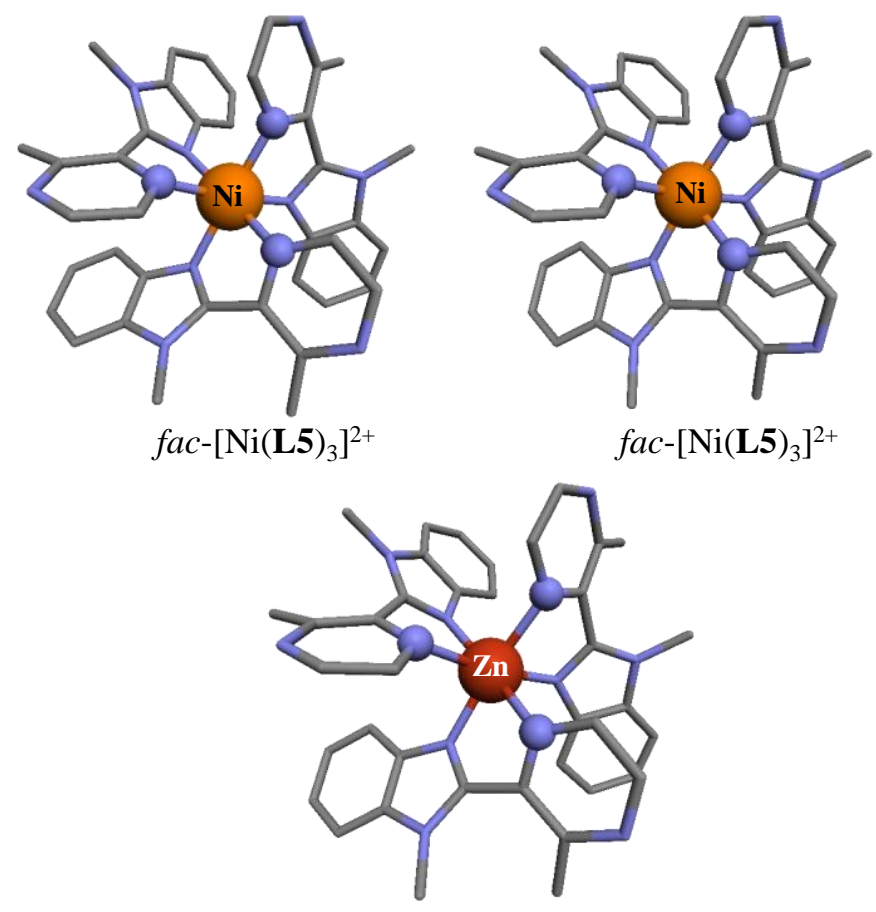

fac- $\left[\mathrm{Zn}(\mathbf{L 5})_{3}\right]^{2+}$

Figure 3. Perspective views of the molecular structures of the $\left[\mathrm{M}(\mathrm{L} 5)_{3}\right]^{2+}$ cations in the crystal structures of $\left[\mathrm{Ni}(\mathbf{L} 5)_{3}\right]\left(\mathrm{BF}_{4}\right)_{2} \cdot \mathrm{H}_{2} \mathrm{O}$ (III, top left), $\left[\mathrm{Ni}(\mathbf{L 5})_{3}\right]\left(\mathrm{BF}_{4}\right)_{2} \cdot 1.75 \mathrm{CH}_{3} \mathrm{CN}$ (V) top right) and $\left[\mathrm{Zn}(\mathbf{L} 5)_{3}\right]\left(\mathrm{BF}_{4}\right)_{2} \cdot 1.5 \mathrm{CH}_{3} \mathrm{CN}(\mathbf{V I})$. The nitrogen atoms of the pyrazine rings bound to the metals are displayed with blue spheres in order to highlight their facial arrangements around the central cation. Color codes: $\mathrm{C}=$ grey, $\mathrm{N}=$ blue. Hydrogen atoms and ionic tetrafluoroborate counter-anions are omitted for clarity. 
Table 1. Structural data for hexa-coordinate metallic centers $\left(\mathrm{Fe}^{\mathrm{II}}, \mathrm{Ni}^{\mathrm{II}}\right.$ or $\left.\mathrm{Zn}^{\mathrm{II}}\right)$ found in the crystal structures of $\left.\left[\mathrm{Fe}(\mathbf{L 5})_{3}\right](\mathrm{ClO})_{4}\right)_{2}(\mathrm{I}),\left[\mathrm{Ni}(\mathbf{L 5})_{3}\right](\mathrm{ClO})_{2}(\mathrm{II})$, $\left[\mathrm{Ni}(\mathbf{L} 5)_{3}\right]\left(\mathrm{BF}_{4}\right)_{2} \cdot \mathrm{H}_{2} \mathrm{O}(\mathbf{I I I}),\left[\mathrm{Zn}(\mathbf{L} 5)_{3}\right]\left(\mathrm{ClO}_{4}\right)_{2}(\mathbf{I V}),\left[\mathrm{Ni}(\mathbf{L} 5)_{3}\right]\left(\mathrm{BF}_{4}\right)_{2} \cdot 1.75 \mathrm{CH}_{3} \mathrm{CN}(\mathbf{V})$, and $\left[\mathrm{Zn}(\mathbf{L} 5)_{3}\right]\left(\mathrm{BF}_{4}\right)_{2} \cdot 1.5 \mathrm{CH}{ }_{3} \mathrm{CN}(\mathbf{V I})$ at $180 \mathrm{~K}$ collecting average bond lengths, interannular intraligand angles $(\alpha)$, interchelate angles $(\beta)$, chelate bite angles $(\gamma)$, and SHAPE's scores.

\begin{tabular}{|c|c|c|c|c|c|c|c|}
\hline & {$\left[\mathrm{Fe}(\mathrm{L} 5)_{3}\right]\left(\mathrm{ClO}_{4}\right)_{2}$} & {$\left[\mathrm{Ni}(\mathrm{L} 5)_{3}\right]\left(\mathrm{ClO}_{4}\right)_{2}$} & {$\left[\mathrm{Ni}(\mathrm{L} 5)_{3}\right]\left(\mathrm{BF}_{4}\right)_{2}$} & {$\left[\mathrm{Ni}(\mathrm{L} 5)_{3}\right]\left(\mathrm{BF}_{4}\right)_{2}$} & {$\left[\mathrm{Zn}(\mathrm{L} 5)_{3}\right]\left(\mathrm{ClO}_{4}\right)_{2}$} & {$\left[\mathrm{Zn}(\mathrm{L} 5)_{3}\right]\left(\mathrm{BF}_{4}\right)_{2}$} & {$\left[\mathrm{Zn}(\mathrm{L} 2)_{3}\right]\left(\mathrm{CF}_{3} \mathrm{SO}_{3}\right)_{2}$} \\
\hline Crystal Structure & I & II & III & $\mathrm{V}$ & IV & VI & \\
\hline Configuration & meridional & meridional & facial & facial & meridional & facial & meridional \\
\hline$d\left(\mathrm{M}-\mathrm{N}_{\mathrm{bz}}\right) / \AA^{\mathrm{a}}$ & $2.14(1)$ & $2.08(2)$ & $2.08(2)$ & $2.07(2)$ & $2.11(2)$ & $2.09(1)$ & $2.09(7)$ \\
\hline$d\left(\mathrm{M}-\mathrm{N}_{\mathrm{pz}}\right) / \AA^{\mathrm{b}}$ & $2.24(3)$ & $2.14(2)$ & $2.12(2)$ & $2.12(1)$ & $2.25(6)$ & $2.26(1)$ & $2.27(3)$ \\
\hline$\alpha /^{\circ}$ & $39(3)$ & $37(3)$ & $39(3)$ & $36(4)$ & $39(3)$ & $38(4)$ & $21(13)$ \\
\hline$\beta /^{\circ}$ & $85(9)$ & $86(7)$ & $88(8)$ & $83.4(9)$ & $85(8)$ & $84(1)$ & $81(8)$ \\
\hline$\gamma /^{\circ}$ & $76.6(7)$ & $78.8(4)$ & $79.1(5)$ & $79.2(7)$ & $77(1)$ & $77.8(8)$ & $76.6(1)$ \\
\hline Octahedron $^{c}$ & 1.85 & 1.41 & $1.25(3)^{d}$ & $1.21(8)^{\mathrm{d}}$ & 1.74 & $1.5(1)^{\mathrm{d}}$ & 1.95 \\
\hline Trigonal Prism ${ }^{c}$ & 15.65 & 15.42 & $15.5(1)^{d}$ & $16.0(2)^{d}$ & 15.39 & $15.9(2)^{d}$ & 12.99 \\
\hline Reference & This work & This work & This work & This work & This work & This work & [60] \\
\hline
\end{tabular}

${ }^{a}$ bz $=$ benzimidazole. ${ }^{\mathbf{b}} \mathrm{pz}=$ pyrazine. ${ }^{\mathbf{c}}$ SHAPE's scores calculated with reference to ideal octahedral and trigonal prismatic geometries [62-66]. ${ }^{\mathbf{d}}$ Average for more than one complex in the asymmetric unit. 
The additional abrupt decrease in the magnetic susceptibility occurring at low temperature ( $T<40 \mathrm{~K}$ ) can be assigned to zero-field splitting (ZFS) of high-spin Fe(II), which was modeled with Equation (7), where $D$ and $E$ are the axial and rhombic ZFS parameters, respectively [70-73].

$$
E_{n}^{0}=D \cdot\left(S_{\hat{z}}^{2}-\frac{S(S+1)}{3}\right)+E \cdot\left(S_{\hat{x}}^{2}-S_{\hat{y}}^{2}\right)
$$

The pseudo-threefold axis characterizing the $\left[\mathrm{FeN}_{6}\right]$ chromophore in $\left[\mathrm{Fe}(\mathbf{L} 5)_{3}\right]\left(\mathrm{ClO}_{4}\right)_{2}$ implies that $E$ can be neglected $(E \sim 0)$. Consequently, the electron-electron interaction splits the $S=2$ manifold at zero magnetic field into three energy levels located at $E_{1}^{0}=-2 D\left(m_{\mathrm{s}}=0\right), E_{2}^{0}=-D\left(m_{\mathrm{s}}= \pm 1\right)$, and $E_{3}^{0}=2 D\left(m_{\mathrm{s}}= \pm 2\right)$. Application of the van Vleck Equation $(8)$, where $k_{\mathrm{B}}=0.695039 \mathrm{~cm}^{-1} \cdot \mathrm{K}^{-1}$ is the Boltzmann constant and $N_{\mathrm{A}}$ is Avogadro number, $E_{n}^{1}$ are first-order spin-only Zeeman effects given in Equation (9), where $\mu_{\mathrm{B}}=-4.6686 \times 10^{-5} \mathrm{~cm}^{-1} \cdot \mathrm{G}^{-1}$ is the Bohr magneton, and $E_{n}^{2}$ stands for the second-order Zeeman effects, leads to a satisfying fit (dotted black trace in Figure 4 with agreement factor AF $=3.73 \times 10^{-3}$ ) with Landé factor $g=2.20(1), D=0.52(1) \mathrm{cm}^{-1}$ and TIP $=-N_{\mathrm{A}} E_{n}^{2}=319(4) \times$ $10^{-6} \mathrm{~cm}^{3} \cdot \mathrm{mol}^{-1}$.

$$
\begin{gathered}
\chi_{\mathrm{M}} T=T \cdot N_{\mathrm{A}} \cdot \frac{\sum_{n}\left[\left(\frac{\left(E_{n}^{1}\right)^{2}}{k_{\mathrm{B}} T}-2 E_{n}^{2}\right) \cdot \exp \left(-\frac{E_{n}^{0}}{k_{\mathrm{B}} T}\right)\right]}{\sum_{n}\left[\exp \left(-\frac{E_{n}^{0}}{k_{\mathrm{B}} T}\right)\right]} \\
E_{n}^{1}=-g \cdot \mu_{\mathrm{B}} \cdot m_{S}
\end{gathered}
$$

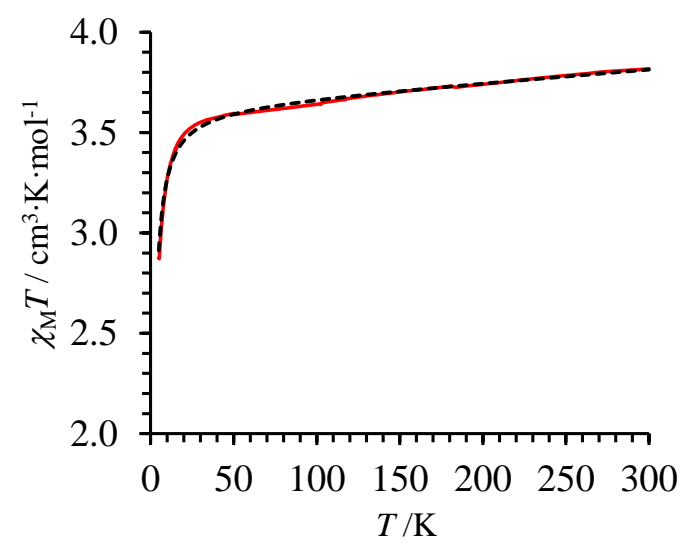

Figure 4. $\chi_{M} T$ versus $T$ plot of the molar magnetic susceptibility $\left(\chi_{M}\right)$ between 5-300 K, corrected for diamagnetism recorded for the complex $\left[\mathrm{Fe}(\mathbf{L} 5)_{3}\right]\left(\mathrm{ClO}_{4}\right)_{2}(\mathrm{I}$, red trace) at 5000 Oe. The dotted black trace shows the best fit (agreement factor $\mathrm{AF}=3.73 \times 10^{-3}$ ) obtained using Equation (8) with $g=2.20(1)$, $D=0.52(1) \mathrm{cm}^{-1}$ and TIP $=-N_{\mathrm{A}} E_{n}^{2}=319(4) \times 10^{-6} \mathrm{~cm}^{3} \cdot \mathrm{mol}^{-1}$.

The latter magnetic data closely matched those reported for the analogous $\left[\mathrm{Fe}(\mathrm{L} 3)_{3}\right]\left(\mathrm{CF}_{3} \mathrm{SO}_{3}\right)_{2}$ complex $\left(g=2.20(2), D=0.85(1) \mathrm{cm}^{-1}[36]\right)$, and demonstrate that our novel $\left[\mathrm{Fe}(\mathbf{L 5})_{3}\right]\left(\mathrm{ClO}_{4}\right)_{2}$ complex, in which the 3-methyl-pyridine group of $\mathbf{L} 3$ is replaced with a 3-methyl-pyrazine group in $\mathbf{L 5}$, is also purely high-spin within the 5-300 K range with no trace of SCO behavior. A careful inspection of the experimental curve around $80 \mathrm{~K}$ (Figure 4) showed a very minor deviation from the theoretical model, which could be tentatively assigned to traces of trapped low-spin form as previously reported for fac- $\left[\mathrm{Fe}(\mathbf{L} 3)_{3}\right]^{2+}$ when it is incorporated into a LaFe triple-stranded helicate [36].

The electronic absorption spectrum recorded for $\left[\mathrm{Fe}(\mathbf{L})_{3}\right]\left(\mathrm{ClO}_{4}\right)_{2}(\mathrm{I})$ in the solid state shows the expected Jahn-Teller split Fe ${ }^{\mathrm{II}}\left({ }^{5} \mathrm{E} \leftarrow{ }^{5} \mathrm{~T}_{2}\right)$ ligand-field transition (Figure 5a) [31]. A deconvolution using two Gaussian functions gives $\widetilde{v}_{\max }=8881 \mathrm{~cm}^{-1}$ and $11,887 \mathrm{~cm}^{-1}$, thus leading to a barycenter at $10,384 \mathrm{~cm}^{-1}$, which provides a direct estimation of $\Delta_{\text {oct }}^{\mathrm{HS}}\left(\mathrm{Fe}^{\mathrm{II}}\right)=10 \mathrm{Dq}$, a value only $700 \mathrm{~cm}^{-1}$ below the minimum of $\Delta_{\mathrm{oct}}^{\mathrm{HS}} \approx 11,000 \mathrm{~cm}^{-1}$ suggested to be the lower limit for inducing spin state equilibria [31]. 
However, the latter criterion strongly depends on the choice of the Racah parameter $B$, which is not easily extracted from the single intrashell $\mathrm{d}-\mathrm{d}$ transition observed in the electronic spectra of high-spin $\mathrm{Fe}^{\mathrm{II}}$ complexes. For this reason, we have recorded the electronic absorption spectrum of the analogous $\mathrm{Ni}^{\mathrm{II}}$ complex $\left[\mathrm{Ni}(\mathbf{L})_{3}\right]\left(\mathrm{BF}_{4}\right)_{2} \cdot \mathrm{H}_{2} \mathrm{O}(\mathrm{III})$, for which the combination of two spin-allowed $\mathrm{d}-\mathrm{d}$ transitions $\mathrm{Ni}\left({ }^{3} \mathrm{~T}_{2} \leftarrow{ }^{3} \mathrm{~A}_{2}\right)$ and $\mathrm{Ni}\left({ }^{3} \mathrm{~T}_{1} \leftarrow{ }^{3} \mathrm{~A}_{2}\right)$ and one spin-forbidden transition $\mathrm{Ni}\left({ }^{1} \mathrm{E} \leftarrow{ }^{3} \mathrm{~A}_{2}\right.$ ) (Figure $5 b$ ) allows a complete characterization of the electronic parameters $\Delta_{\text {oct }}\left(\mathrm{Ni}^{\mathrm{II}}\right), B\left(\mathrm{Ni}^{\mathrm{II}}\right)$, and $C\left(\mathrm{Ni}^{\mathrm{II}}\right)$ with the help of Equations (10)-(13) [74,75].

$$
\begin{gathered}
E\left({ }^{3} \mathrm{~A}_{2 \mathrm{~g}}\right)=0 \\
E\left({ }^{1} \mathrm{E}_{\mathrm{g}}\right)=8 B+2 C-\frac{6 B^{2}}{\Delta_{\text {oct }}} \\
E\left({ }^{3} \mathrm{~T}_{2 \mathrm{~g}}\right)=\Delta_{\text {otc }} \\
E\left({ }^{3} \mathrm{~T}_{1 \mathrm{~g}}\right)=1.5 \Delta_{\text {oct }}+7.5 B-0.5 \sqrt{225 B^{2}+\Delta_{\text {oct }}{ }^{2}-18 \Delta_{\text {oct }} B}
\end{gathered}
$$
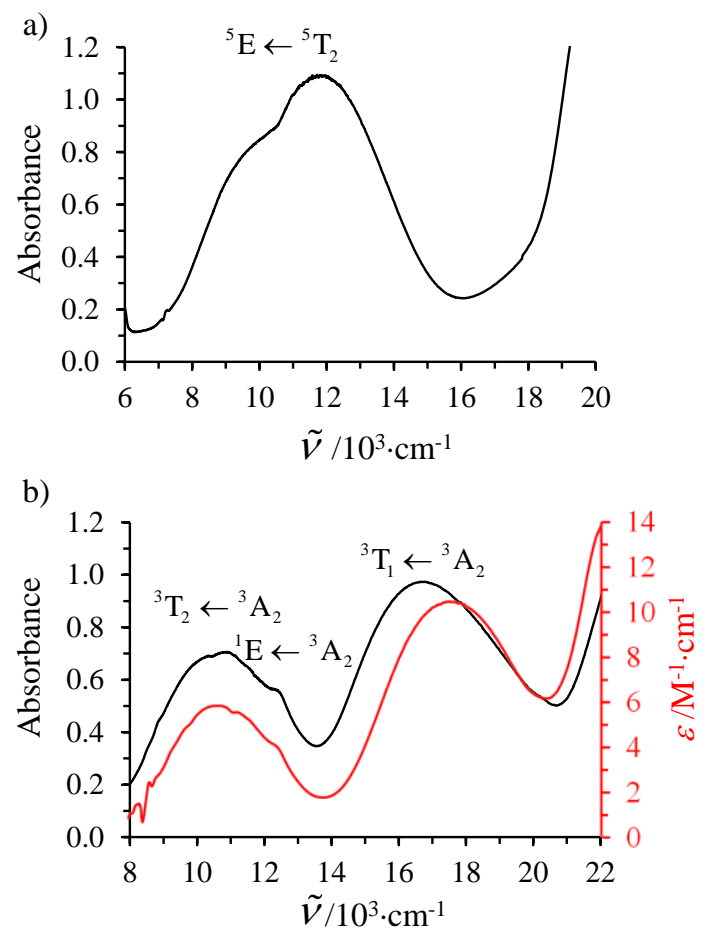

Figure 5. Electronic absorption spectra recorded at $298 \mathrm{~K}$ for (a) $\left[\mathrm{Fe}(\mathbf{L 5})_{3}\right]\left(\mathrm{ClO}_{4}\right)_{2}(\mathrm{I})$ in the solid state and $(\mathbf{b})\left[\mathrm{Ni}\left(\mathrm{L}_{5}\right)_{3}\right]\left(\mathrm{BF}_{4}\right)_{2} \cdot \mathrm{H}_{2} \mathrm{O}(\mathrm{III})$ in the solid state (black trace, left axis) and in acetonitrile solution $(0.1 \mathrm{M}$, red trace, right axis).

A Gaussian deconvolution of the visible part of the absorption spectrum into three peaks yielded two broad bands, diagnostic for the spin-allowed, but parity-forbidden, transitions at $10,672 \mathrm{~cm}^{-1}$ $\left({ }^{3} \mathrm{~T}_{2} \leftarrow{ }^{3} \mathrm{~A}_{2}\right)$ and $16,763 \mathrm{~cm}^{-1}\left({ }^{3} \mathrm{~T}_{1} \leftarrow{ }^{3} \mathrm{~A}_{2}\right.$; Table S16), together with a third weaker band at $12,584 \mathrm{~cm}^{-1}$, which can be ascribed to the spin-forbidden ${ }^{1} \mathrm{E} \leftarrow{ }^{3} \mathrm{~A}_{2}$ component (Figure $5 \mathrm{~b}$ ). Subsequent non-linear least-squares fits of the energies of these transitions with Equations (10)-(13) provides a first rough set of ligand field strength $\Delta_{\text {oct }}=10,672 \mathrm{~cm}^{-1}$ and Racah parameters $B=760 \mathrm{~cm}^{-1}$ and $C=3413 \mathrm{~cm}^{-1}$ (Table S16). However, the mixing of the spin-allowed ${ }^{3} \mathrm{~T}_{2} \leftarrow{ }^{3} \mathrm{~A}_{2}$ transition with the spin-forbidden ${ }^{1} \mathrm{E} \leftarrow{ }^{3} \mathrm{~A}_{2}$ transition via spin-orbit coupling for apparent ligand field strengths around $11,000-12,000$ $\mathrm{cm}^{-1}$, as found for $\left[\mathrm{Ni}(\mathbf{L} 5)_{3}\right]\left(\mathrm{BF}_{4}\right)_{2} \cdot \mathrm{H}_{2} \mathrm{O}$, requires further refinements [76]. A detailed analysis of a series of $\mathrm{Ni}^{\mathrm{II}}$ complexes led Hancock and coworkers to propose three empirical Equations (14)-(16) to obtain more reliable ligand field strengths $\Delta_{\text {oct }}$ and Racah parameters $B$ and $C$ in $\mathrm{cm}^{-1}$ units $\left(\varepsilon_{1}\right.$ and 
$\varepsilon_{2}$ are the extinction coefficients at the observed frequencies of the ${ }^{1} \mathrm{E} \leftarrow{ }^{3} \mathrm{~A}_{2}$ transition and ${ }^{3} \mathrm{~T}_{2} \leftarrow{ }^{3} \mathrm{~A}_{2}$ transition, respectively) [76]. The analysis of the experimental absorption spectra using this model gives the corrected parameters gathered in Table 2 for the $\left[\mathrm{Ni}(\mathbf{L})_{3}\right]^{2+}$ and $\left[\mathrm{Ni}(\mathbf{L} 2)_{3}\right]^{2+}$ chromophores.

$$
\begin{gathered}
\Delta_{\mathrm{oct}}=10 \mathrm{Dq}=10630+1370\left(\varepsilon_{1} / \varepsilon_{2}\right) \\
B=1120-0.022 \cdot \Delta_{\mathrm{oct}} \\
C=15 B-9975
\end{gathered}
$$

\begin{tabular}{|c|c|c|c|}
\hline & $\begin{array}{c}{\left[\mathrm{Ni}(\mathrm{L})_{3}\right]\left(\mathrm{BF}_{4}\right)_{2}} \\
\quad(\text { solid })\end{array}$ & $\begin{array}{c}{\left[\mathrm{Ni}(\mathrm{L} 5)_{3}\right]^{2+}} \\
\left(0.1 \mathrm{M} \mathrm{CH}_{3} \mathrm{CN}\right)\end{array}$ & $\begin{array}{c}{\left[\mathrm{Ni}(\mathrm{L} 2)_{3}\right]^{2+}} \\
\left(0.1 \mathrm{M} \mathrm{CH}_{3} \mathrm{CN}\right)\end{array}$ \\
\hline$\Delta_{\mathrm{oct}} / \mathrm{cm}^{-1}$ & 11,631 & 11,555 & 11,605 \\
\hline $\mathrm{B} / \mathrm{cm}^{-1}$ & 864 & 866 & 865 \\
\hline $\mathrm{C} / \mathrm{cm}^{-1}$ & 2986 & 3012 & 2995 \\
\hline$\Delta_{\mathrm{oct}} / B$ & 13.5 & 13.3 & 13.4 \\
\hline$C / B$ & 3.45 & 3.48 & 3.46 \\
\hline$\beta^{a}$ & 0.83 & 0.83 & 0.83 \\
\hline
\end{tabular}

Table 2. Ligand-field strengths (oct) and Racah parameters $(B, C)$ computed with Equations (14)-(16) for $\left[\mathrm{Ni}(\mathbf{L} 5)_{3}\right]\left(\mathrm{BF}_{4}\right)_{2} \cdot \mathrm{H}_{2} \mathrm{O}(\mathrm{III})$ in the solid state and in $0.1 \mathrm{M}$ acetonitrile solution at $298 \mathrm{~K}$.

The refined $\Delta_{\text {oct }}, B$ and $C$ parameters computed for $\left[\mathrm{Ni}(\mathbf{L} 5)_{3}\right]^{2+}$ (Table 2) almost exactly matched those previously reported for the unconstrained $\left[\mathrm{Ni}(\mathbf{L} 2)_{3}\right]^{2+}$ complex, for which the related $\left[\mathrm{Fe}(\mathbf{L} 2)_{3}\right]^{2+}$ complex displayed spin-crossover behavior above room temperature $\left(T_{1 / 2} \sim 400 \mathrm{~K}\right.$ in the solid state, $T_{1 / 2} \sim 350 \mathrm{~K}$ in acetonitrile solution [35]). Moreover $\Delta_{\text {oct }}\left(\left[\mathrm{Ni}(\mathbf{L 5})_{3}\right]^{2+}\right)=11,630 \mathrm{~cm}-^{1}$ is compatible with the ligand field range $11,200 \leq \Delta_{\text {oct }}\left(\mathrm{Ni}^{\mathrm{iI}}\right) \leq 12,400 \mathrm{~cm}^{-1}$ established by Busch and coworkers [78] as a reliable and useful benchmark for predicting and rationalizing the spin-crossover of the related $\mathrm{Fe}^{\mathrm{II}}$ complexes [40]. The absence of SCO behavior depicted by $\left[\mathrm{Fe}(\mathbf{L} 5)_{3}\right]\left(\mathrm{ClO}_{4}\right)_{2}$ is thus difficult to assign to some inadequate electronic properties of the $\left[\mathrm{FeN}_{6}\right]$ chromophore, but more probably to the impossibility of the coordination sphere to shrink for adopting short-enough Fe-N bonds compatible with low-spin $\mathrm{Fe}^{\mathrm{II}}$. This pure sterical limitation can be tentatively assigned to the intraligand sterical constraints programmed to occur between the methyl groups bound to the pyrazine and benzimidazole rings in each coordinated syn-L5 ligand in $\left[\mathrm{Fe}(\mathbf{L})_{3}\right]^{2+}$. However, packing forces operating in the solid state may be as important, or even much larger than intramolecular constraints and a definitive assessment requires the extension of our analysis to isolated complexes in solution, where intermolecular interactions are significantly reduced.

Stabilities and electronic properties of the pseudo-octahedral complexes $\left[\mathrm{M}(\mathrm{L} 5)_{3}\right] \mathrm{X}_{2}(\mathrm{M}=\mathrm{Fe}$, $\mathrm{Ni}, \mathrm{Zn}$ and $\mathrm{X}=\mathrm{BF}_{4}, \mathrm{CF}_{3} \mathrm{SO}_{3}$ ) were obtained in acetonitrile solutions. Following the procedure previously detailed for analogous $\left[\mathrm{Zn}(\mathbf{L} \boldsymbol{k})_{3}\right]^{2+}[60]$ and $\left[\mathrm{Fe}(\mathbf{L} \boldsymbol{k})_{3}\right]^{2+}[35]$ with the didentate ligands $\mathbf{L 1}$ and $\mathbf{L} 2$, spectrophotometric titrations of submillimolar concentrations of $\mathbf{L} 5$ with $\mathrm{M}\left(\mathrm{CF}_{3} \mathrm{SO}_{3}\right)_{2}(\mathrm{M}=$ $\mathrm{Ni}, \mathrm{Zn}$ ) in dry acetonitrile (Figure $6 \mathrm{a}, \mathrm{b}$ and Figure S11a,b) showed the successive formation of two absorbing complexes $\left[\mathrm{M}(\mathbf{L} 5)_{n}\right]^{2+}(n=2,1$; equilibria (17)-(18)) as ascertained by their independent eigenvectors found in the factor analyses (Figure $6 c$ and Figures S11c-S12c) [48-50] and their satisfying re-constructed absorption spectra (Figure 6d and Figure S11d) [51-53].

$$
\begin{gathered}
\mathrm{M}^{2+}+\mathbf{L} 5[\mathrm{M}(\mathbf{L} 5)]^{2+} \beta_{1,1}^{\mathrm{M}, \mathbf{L} 5} \\
\mathrm{M}^{2+}+2 \mathbf{L} 5\left[\mathrm{M}(\mathbf{L} 5)_{2}\right]^{2+} \beta_{1,2}^{\mathrm{M}, \mathbf{L} 5} \\
\mathrm{M}^{2+}+3 \mathbf{L} 5\left[\mathrm{M}(\mathbf{L} 5)_{3}\right]^{2+} \beta_{1,3}^{\mathrm{M}, \mathbf{L} 5}
\end{gathered}
$$


The $4000 \mathrm{~cm}-1$ red-shift of the ligand-centered $\pi^{*} \leftarrow \pi$ transition observed upon complexation to $\mathrm{M}^{\mathrm{II}}$ (Figure 6a and Figure S11a) is diagnostic for the anti $\rightarrow$ syn conformational change of the $\alpha, \alpha^{\prime}$ diimine unit accompanying the coordination of $\mathbf{L} 5$ to $\mathrm{M}^{\mathrm{II}}$ [79,80]. Non-linear least-square fits [51-53] of the spectrophotometric data to equilibria (17)-(18) provide the macroscopic cumulative formation constants gathered in Table 3 (entries 3-4) together with speciation curves [81] showing a maximum formation of ca. $50 \%$ of the ligand speciation under the form of $\left[\mathrm{M}(\mathbf{L} 5)_{2}\right]^{2+}$ at submillimolar concentrations (Figure 6e and Figure S11e). Attempts to consider the formation of an additional $\left[\mathrm{M}(\mathrm{L} 5)_{3}\right]^{2+}$ complex according to equilibrium (19) only failed in our hands, which suggests that the $\beta_{1,3}^{\mathrm{M}, \mathrm{L} 5}$ constant is too low for providing significant quantities of the latter complex at this concentration.
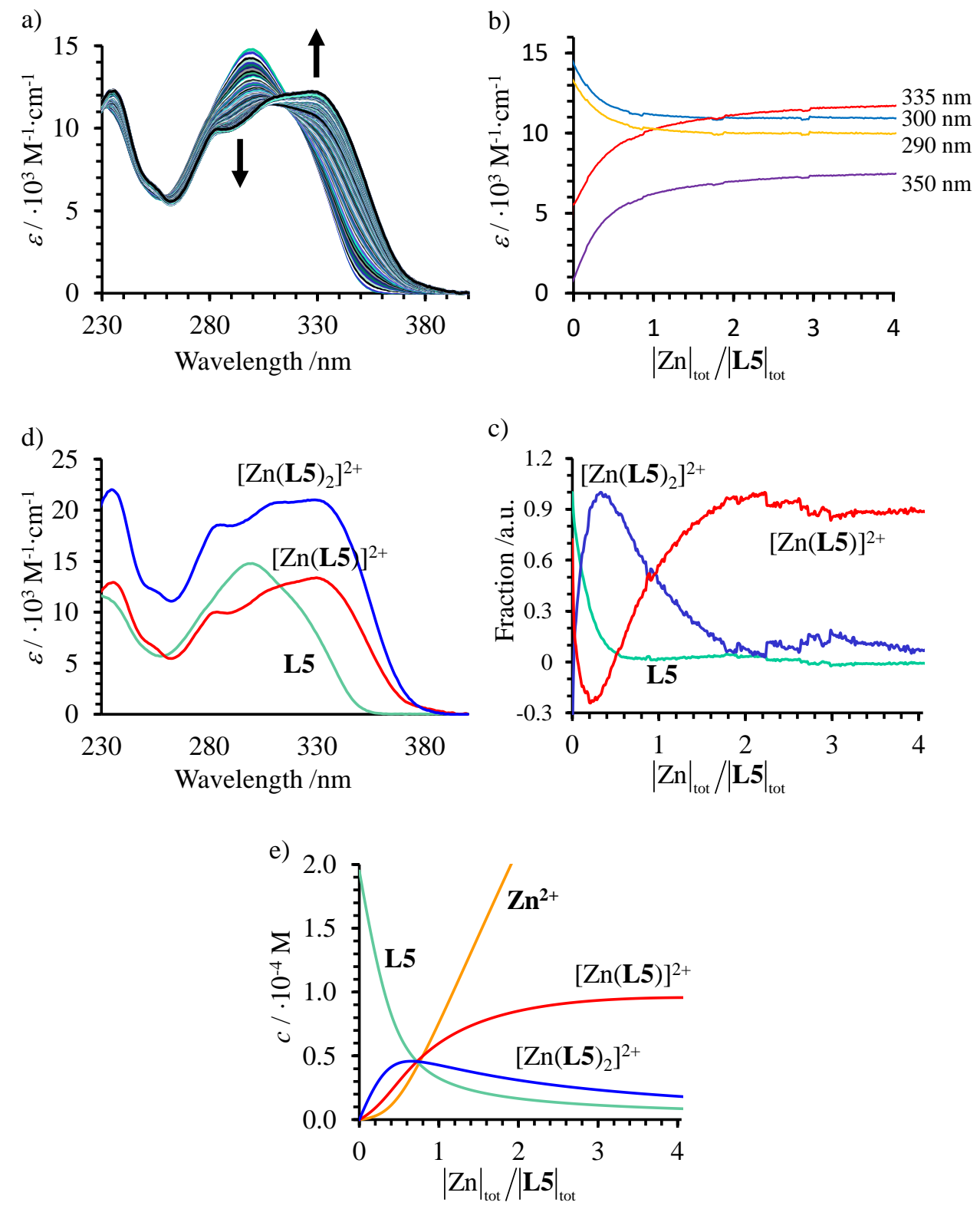

Figure 6. (a) Variation of absorption spectra and (b) corresponding variation of observed molar extinctions at different wavelengths recorded for the spectrophotometric titration of L5 with $\mathrm{Zn}\left(\mathrm{CF}_{3} \mathrm{SO}_{3}\right)_{2}$ (total ligand concentration: $2.0 \times 10^{-4}$ mol.dm ${ }^{-3}$ in acetonitrile, $298 \mathrm{~K}$ ). (c) Evolving factor analysis using four absorbing eigenvectors [48-50], (d) re-constructed individual electronic absorption spectra [51-53] and (e) associated computed speciation [81]. 
Table 3. Cumulative stability constants $\left(\log \left(\beta_{1, n}^{\mathrm{M}, \mathrm{L} k}\right)\right.$, Equations (17)-(19), intrinsic affinities $\left(\Delta G^{\mathrm{M}, \mathrm{L} k}=\right.$ $\left.-R T \ln \left(f^{\mathrm{M}, \mathrm{L} k}\right)\right)$ and global interligand interactions $\left(\Delta E^{\mathbf{L} k, \mathbf{L} k}=-R T \ln \left(u^{\mathbf{L} k, \mathbf{L} k}\right)\right)$ estimated in acetonitrile at $298 \mathrm{~K}$.

\begin{tabular}{ccccc}
\hline Ligand & \multicolumn{3}{c}{ L5 } & \multicolumn{2}{c}{ L2 } \\
\hline Metal & Ni(II) & Zn(II) & Zn(II) & Fe(II) \\
\hline $\log \left(\beta_{1,1}^{\mathrm{M}, \mathrm{L} k}\right)$ & $4.27(1)$ & $4.38(1)$ & $6.89(3)$ & $6.045(9)$ \\
$\log \left(\beta_{1, \mathrm{M}, \mathrm{L} k}^{\mathrm{M}}\right)$ & $8.73(1)$ & $8.73(1)$ & $12.76(5)$ & $11.49(2)$ \\
$\log \left(\beta_{1,3}^{\mathrm{M}, \mathrm{L} k}\right)$ & $12.0^{a}$ & $12.7^{a}$ & $17.64(5)$ & $16.88(2)$ \\
$\Delta G^{\mathrm{M}, \mathrm{L} k} / \mathrm{kJ} / \mathrm{mol}$ & $-16.5(1)$ & $-17.1(7)$ & $-31.1(3)$ & $-25.9(8)$ \\
$\Delta E^{\mathbf{L} k, \mathrm{~L} k} / \mathrm{kJ} / \mathrm{mol}$ & $-4.9(1)$ & $-3.6(1)$ & $1.1(4)$ & $-2.7(9)$ \\
Reference & This work & This work & {$[60]$} & {$[35]$} \\
\hline
\end{tabular}

${ }^{a}$ Computed with Equation (22).

According to the site-binding model [82,83], the first stability constant $\beta_{1,1}^{\mathrm{M}, \mathrm{L} k}$ reflects the simple intermolecular affinity $f^{\mathrm{M}, \mathrm{L} k}$ between the didentate ligand $\mathbf{L} \boldsymbol{k}$ and the entering $\mathrm{M}^{\mathrm{II}}$ cation (including the change in solvation, Equation (20)) modulated by a pure entropic contribution $\omega_{1,1}=24$ [60] produced by the change in rotational entropies accompanying the transformation of the reactants into products, a parameter often referred to as the statistical factor $[84,85]$.

$$
\beta_{1,1}^{\mathrm{M}, \mathrm{L} k}=24 f^{\mathrm{M}, \mathrm{L} k}
$$

Applying Equation (20) to the stability constants $\beta_{1,1}^{\mathrm{M}, \mathrm{L} k}$ collected in Table 3 (entry 3) leads to intrinsic free energy affinities $\Delta G^{\mathrm{M}, \mathrm{L} k}=-R T \ln \left(f^{\mathrm{M}, \mathrm{L} k}\right)=-R T \ln \left(\beta_{1,1}^{\mathrm{M}, \mathrm{L} k} / 24\right)$ (entry 6), which are roughly reduced by a factor two in going from the 5-methyl-pyrazine ligand $\mathbf{L} 2$ to the 3-methyl-pyrazine analogue $\mathbf{L 5}$, as illustrated for $[\mathrm{Zn}(\mathbf{L} 2)]^{2+}\left(\Delta G^{\mathrm{Zn}, \mathbf{L} 2}=-31.1(3) \mathrm{kJ} \cdot \mathrm{mol}^{-1}\right)$ and $[\mathrm{Zn}(\mathbf{L} 5)]^{2+}\left(\Delta G^{\mathrm{Zn}, \mathbf{L} \mathbf{5}}=\right.$ $\left.-17.1(7) \mathrm{kJ} \cdot \mathrm{mol}^{-1}\right)$.

The fixation of two ligands to give $\left[\mathrm{M}(\mathbf{L} \boldsymbol{k})_{2}\right]^{2+}$ obeying equilibrium (18) requires twice the intermolecular metal-ligand affinity, a statistical factor of $\omega_{1,2}=120$, which takes into account all the possible geometric isomers [60] and the operation of allosteric cooperativity factors $u^{\mathrm{L} k, \mathrm{~L} k}$ measuring the extra energy cost $\left(u^{\mathrm{L} k, \mathrm{~L} k}<1\right)$, respectively, energy benefit $\left(u^{\mathrm{L} k, \mathrm{~L} k}>1\right)$ produced by the binding of two ligands to the same metal (Equation (21)) [82,83,86].

$$
\beta_{1,2}^{\mathrm{M}, \mathrm{L} k}=120\left(f^{\mathrm{M}, \mathrm{L} k}\right)^{2} u^{\mathrm{L} k, \mathrm{~L} k}
$$

Applying Equation (21) to the stability constants $\beta_{1,2}^{\mathrm{M}, \mathrm{L} k}$ (entry 4 in Table 3) with the help of the intrinsic affinities $f^{\mathrm{M}, \mathrm{L} k}=\exp \left(-\Delta G^{\mathrm{M}, \mathrm{L} k} / R T\right)$ deduced from $\Delta G^{\mathrm{M}, \mathrm{L} k}$ (entry 6 in Table 3) provides interligand free energies interactions $\Delta E^{\mathrm{L} k, \mathrm{~L} k}=-R T \ln \left(u^{\mathrm{L} k, \mathrm{~L} k}\right)=-R T \ln \left(\beta_{1,2}^{\mathrm{M}, \mathrm{L} k} / 120\right)-2 \Delta G^{\mathrm{M}, \mathrm{L} k}$ (entry 7 in Table 3) close to zero (non-cooperativity) for $\left[\mathrm{M}(\mathbf{L} 2)_{2}\right]^{2+}$ complexes, but negative (positive cooperativity) for $\left[\mathrm{M}(\mathrm{L} 5)_{2}\right]^{2+}$. However, the neglect of the expected $\left[\mathrm{M}(\mathrm{L} 5)_{3}\right]^{2+}$ for modeling the spectrophotometric titrations results in a slight overestimation of the second cumulative constant $\beta_{1,2}^{\mathrm{M}, \mathrm{L} k}$, fully compatible with the apparent, but probably not pertinent, minor positive cooperativity observed for the successive binding of $\mathbf{L} 5$ ligands to $\mathrm{M}^{2+}$ centers. Finally, the introduction of the estimated intrinsic affinities and interligand interactions into Equation (22) allows some predictions concerning the inaccessible third cumulative stability constants [35].

$$
\beta_{1,3}^{\mathrm{M}, \mathrm{L} k}=64\left(f^{\mathrm{M}, \mathbf{L} k}\right)^{3}\left(u^{\mathbf{L} k, \mathbf{L} k}\right)^{3}
$$


The resulting values of $\log \left(\beta_{1,3}^{\mathrm{M}, \mathrm{L} 5}\right) \approx 12.0$ (Table 3, entry 5) correspond to a reduction by five orders of magnitude with respect to $\log \left(\beta_{1,3}^{\mathrm{M}, \mathrm{L} 2}\right) \approx 17.0$ experimentally found with the less constrained ligand L2. There is no doubt that the hindered planar arrangement of the two aromatic heterocycles in L5 has a deep impact on the strength of the $\mathrm{M}-\mathrm{N}$ bonds because of the misalignment of the nitrogen lone pairs with metal d-orbitals in pseudo-octahedral geometry. Nevertheless, at $1 \mathrm{M}$ concentration of $\mathbf{L} 5$ in acetonitrile, the ligand speciation curve computed [81] by using $\beta_{1, n}^{\mathrm{M}, \mathbf{L} 5}(n=1-3)$ gathered in Table 3 shows that $\left[\mathrm{M}(\mathrm{L} 5)_{3}\right]^{2+}(\mathrm{M}=\mathrm{Ni}, \mathrm{Zn})$ corresponds to more than $90 \%$ of the distribution at the stoichiometric M:L5 = 1/3 ratio (Figure S12). At a total ligand concentration of $0.1 \mathrm{M}$ in acetonitrile, $\left[\mathrm{Ni}(\mathbf{L} 5)_{3}\right]^{2+}$ stands for $84 \%$ of the ligand speciation and its absorption spectrum closely matches that recorded for related solid state samples (Figure 5). Repeating the detailed analysis described in the previous section (Equations (10)-(16)) provides ligand-field strengths $\left(\Delta_{\text {oct }}\right)$ and Racah parameters $(B, C)$ similar to those found in the solid state (Table 2), especially for the crucial ratio $\Delta_{\text {oct }} / B=13.3$, which is identical for $\left[\mathrm{Ni}(\mathbf{L} 2)_{3}\right]^{2+}$ and $\left[\mathrm{Ni}(\mathbf{L} 5)_{3}\right]^{2+}$, both in solution and in the solid state. In other words, the moving of the methyl group connected to the pyrazine ring from the 5-position in $\mathbf{L} 2$ to the 3-position in $\mathbf{L} 5$ indeed strongly reduces the affinity of the didentate ligand for $\mathrm{Ni}$ (II) in solution, but only has a weak effect on the ligand field strengths and on the $\mathrm{Ni}-\mathrm{N}$ (or $\mathrm{Zn}-\mathrm{N}$ ) bond length. Interestingly, the variable-temperature ${ }^{1} \mathrm{H}$ NMR spectra recorded for diamagnetic $\left[\mathrm{Zn}(\mathbf{L 5})_{3}\right]^{2+}(>80 \%$ for a total concentration of $0.1 \mathrm{M}$ in $\mathrm{CD}_{3} \mathrm{CN}$ in the 233-333 $\mathrm{K}$ range, Figure S13) showed a single set of signals compatible with the exclusive formation of an averaged $C_{3}$-symmetrical species with no contribution from either blocked facial and meridional isomers or from partial decomplexation to give $\left[\mathbf{Z n}(\mathbf{L} 5)_{2}\right]^{2+}+\mathbf{L} 5$ (equilibrium (19)). These observations are in contrast with the detection at low temperature in $\mathrm{CD}_{3} \mathrm{CN}$ of two well-resolved spectra characteristics of a slow exchange operating between $f a c-\left[\mathrm{Zn}(\mathbf{L} 2)_{3}\right]^{2+}$ and $m e r-\left[\mathrm{Zn}(\mathbf{L} 2)_{3}\right]^{2+}[60]$, and suggests that the weaker stability constants are accompanied by faster ligand exchange processes around $\mathrm{Zn}^{2+}$ in $\left[\mathrm{Zn}(\mathbf{L} 5)_{3}\right]^{2+}$. This decrease in affinity reaches its paroxysm for the coordination of $\mathrm{Fe}^{2+}$ since the spectrophotometric titration of $\mathbf{L} \mathbf{5}$ with $\mathrm{Fe}\left(\mathrm{CF}_{3} \mathrm{SO}_{3}\right) 2$ conducted at submillimolar concentration displays only a minor drift of the absorption spectra with no pronounced end point (Figure 7).
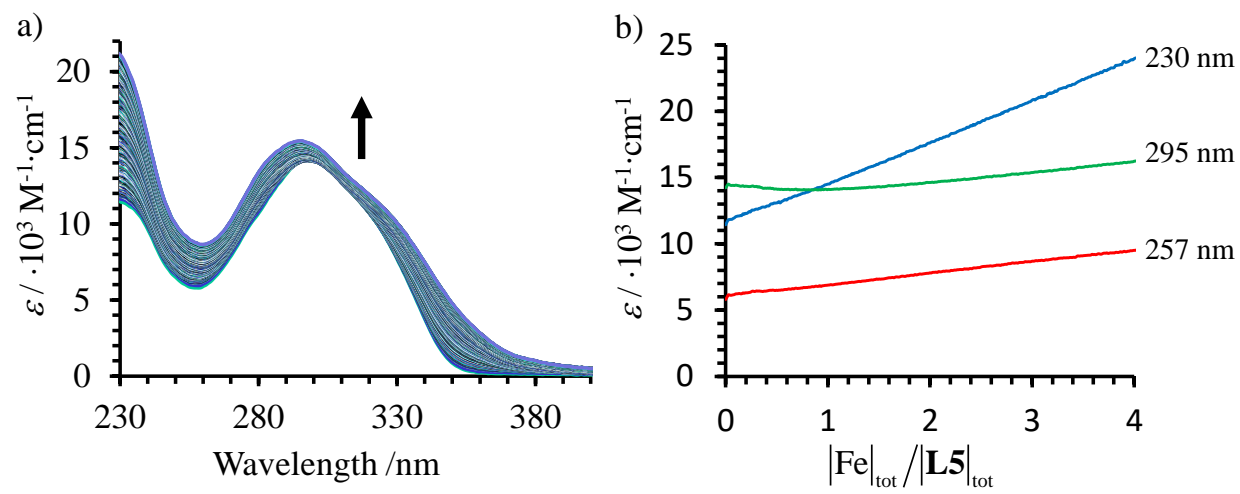

Figure 7. (a) Variation of absorption spectra and (b) corresponding variation of observed molar extinctions at different wavelengths recorded for the spectrophotometric titration of $\mathbf{L} 5$ with $\mathrm{Fe}\left(\mathrm{CF}_{3} \mathrm{SO}_{3}\right)_{2}$ (total ligand concentration: $2.0 \cdot 10^{-4} \mathrm{~mol} \cdot \mathrm{dm}^{-3}$ in acetonitrile, $298 \mathrm{~K}$.

Attempts to model these limited variations within the frame of equilibria (17)-(18) only failed. The amount of $\left[\mathrm{Fe}(\mathbf{L} 5)_{n}\right]^{2+}$ in solution is strongly limited by (very) low cumulative stability constants, a situation produced by the impossibility for $\mathrm{Fe}^{\mathrm{II}}$ to adopt a compact low-spin configuration in the sterically constrained complex [35]. In the absence of a significant amount of $\left[\mathrm{Fe}(\mathbf{L 5})_{3}\right]^{2+}$ complexes in solution, no spin state equilibria could be investigated for this system. 


\section{Conclusions}

Having established that the shift of the methyl group connected to the pyridine ring in going from the didentate ligand $\mathbf{L} \mathbf{1}$ (5-position) to L3 (3-position) was accompanied by a drift of the transition temperature in the associated spin-crossover complexes from $T_{1 / 2} \sim 310 \mathrm{~K} \mathrm{in}\left[\mathrm{Fe}(\mathbf{L} \mathbf{1})_{3}\right]^{2+}[34]$ to $T_{1 / 2}$ $\sim 50 \mathrm{~K}$ in a pure facial version of the $\left[\mathrm{Fe}(\mathbf{L} 3)_{3}\right] 2+$ chromophore [36], we attempted in this work to transpose this trend for pyrazine analogues $\mathbf{L} \mathbf{2}$ and $\mathbf{L} 5$ with the preparation of the missing member of the series $\left[\mathrm{Fe}(\mathbf{L} 5)_{3}\right]^{2+}$ (3-methyl-pyrazine), for which an ideal $T_{1 / 2} \sim 90 \mathrm{~K}$ could be naively predicted since $T_{1 / 2} \sim 350 \mathrm{~K}$ in $\left[\mathrm{Fe}(\mathbf{L} 2)_{3}\right] 2+$ (5-methyl-pyrazine). At first sight, this approach appeared to be promising since the molecular structures of pseudo-octahedral $\left[\mathrm{M}(\mathrm{L} 2)_{3}\right]^{2+}$ and $\left[\mathrm{M}(\mathrm{L} 5)_{3}\right]^{2+}\left(\mathrm{M}=\mathrm{Ni}^{\mathrm{II}}\right.$ and $\mathrm{Zn}^{\mathrm{II}}$ ) were comparable, except for the expected larger interannular twist between the connected aromatic rings produced by the close methyl groups in bound L5. The diagnostic ratio $\Delta / B=13.3$ was identical for both $\mathrm{Ni}^{\mathrm{iI}}$ complexes, thus pointing to electronic properties also compatible with the induction of $\mathrm{SCO}$ behavior in the analogous $\mathrm{Fe}^{\mathrm{II}}$ complexes. Surprisingly and disappointingly, $\left[\mathrm{Fe}(\mathbf{L})_{3}\right]^{2+}$ exists as a pure high spin complex within the 5-300 $\mathrm{K}$ range with no trace of spin state equilibrium. A thorough analysis of its thermodynamic formation in solution highlights a huge decrease in affinity of the ligand $\mathbf{L}$, compared with $\mathbf{L} 2$, for its binding to $\mathrm{M}^{2+}$ cations despite the presence of the same nitrogen donor atoms. Compared with the pyridine analogues $\left[\mathrm{M}(\mathrm{L} 3)_{3}\right]^{2+}$, which possess similar intra-strand sterical constraints (3-methyl substituents), the much weaker $\sigma$-donating N-pyrazine donor atoms were unable to compensate for the additional interstrand constraints required for chelating $\mathbf{L} 5$ around $\mathrm{M}^{2+}$. This limiting factor, which can be compared to a sort of arm wrestling match, is amplified with small cations and low-spin $\mathrm{Fe}^{\mathrm{II}}$ cannot be complexed to L5.

Supplementary Materials: The following are available online at http:/www.mdpi.com/2624-8549/2/2/15/s1. Tables S1-S16 collecting elemental analyses, crystallographic, and photophysical data. Figures S1-S13 showing the crystal structures, ${ }^{1} \mathrm{H}$ NMR spectra, spectrophotometric titrations, and theoretical calculations.

Author Contributions: Conceptualization, T.L. and C.P.; Methodology and practical chemical and spectroscopic studies, N.D. and T.L.; Crystallography, L.G. and C.B.; Writing draft report, N.D.; Writing of manuscript and editing, C.P., N.D., T.L., and C.B.; Project administration and funding acquisition C.P. All authors have read and agreed to the published version of the manuscript.

Funding: Financial support from the Swiss National Science Foundation is gratefully acknowledged (grant number: 200020_178758).

Acknowledgments: The authors thank Kerry Buchwalder for performing the elemental analysis and for efficient technical support.

Conflicts of Interest: The authors declare no conflicts of interest.

\section{References}

1. Jorgensen, C.K. Modern Aspects of Ligand Field Theory; North Holland Publishing Company: Amsterdam, The Netherland, 1971.

2. Mingos, D.M.P. Structure and Bonding: The Early Days. Struct. Bond. 2016, 172, 1-18.

3. Bethe, H. Termaufspaltung in Kristallen. Ann. Phys. 1929, 3, 133-208. [CrossRef]

4. Gütlich, P.; Goodwin, H.A. Spin-crossover-An Overall Perspective. Top. Curr. Chem. 2004, 233, 1-47.

5. Van Vleck, J.H. The Theory of Electric and Magnetic Susceptibilities; Clarendon Press: Oxford, UK, 1932.

6. Pauling, L. The Nature of the Chemical Bond. III. The Transition from One Extreme Bond Type to Another. J. Am. Chem. Soc. 1932, 54, 988-1003. [CrossRef]

7. Corryell, C.D.; Stittand, F.; Pauling, L. The Magnetic Properties and Structure of Ferrihemoglobin (Methemoglobin) and Some of its Compounds. J. Am. Chem. Soc. 1937, 59, 633-642. [CrossRef]

8. Cambi, L.; Szego, L. The Magnetic Susceptibility of Complex Compounds. Ber. Dtsch. Chem. Ges. 1931, 64, 2591-2598. [CrossRef]

9. Cambi, L.; Szego, L.; Cagnasso, A. The Magnetic Susceptibility of Complexes. IV. Ferric N,N-Dipropyldithiocarbamates. Atti Accad. Lincei 1932, 15, 266-271. 
10. Cambi, L.; Szego, L.; Cagnasso, A. The Magnetic Susceptibility of Complexes. V. Iron dibutyldithiocarbamates. Atti Accad. Lincei 1932, 15, 329-335.

11. Spin-Crossover in Transition Metal Compounds I-III; Gütlich, P.; Goodwin, H.A. (Eds.) Springer: Berlin/Heidelberg, Germany, 2004.

12. Spin-Crossover Materials; Halcrow, M.A. (Ed.) John Wiley \& Sons, Ltd: Chichester, UK, 2013.

13. Olguin, J. Unusual Metal Centres/Coordination Spheres in Spin Crossover Compounds. Coord. Chem. Rev. 2020, 407, 213148. [CrossRef]

14. Gütlich, P.; Garcia, Y.; Goodwin, H.A. Spin-crossover Phenomena in Fe(II) Complexes. Chem. Soc. Rev. 2000, 29, 419-427. [CrossRef]

15. Halcrow, M.A. The Spin-States and Spin Transitions of Mononuclear Iron(II) Complexes of Nitrogen-Donor Ligands. Polyhedron 2007, 26, 3523-3576. [CrossRef]

16. Gaspar, A.B.; Seredyuk, M. Spin-crossover in Soft Matter. Coord. Chem. Rev. 2014, 268, 41-58. [CrossRef]

17. Brooker, S. Spin-crossover with Thermal Hysteresis: Practicalities and Lessons Learnt. Chem. Soc. Rev. 2015, 44, 2880-2892. [CrossRef] [PubMed]

18. Hogue, R.W.; Singh, S.; Brooker, S. Spin-crossover in Discrete Polynuclear Iron(II) Complexes. Chem. Soc. Rev. 2018, 47, 7303-7338. [CrossRef] [PubMed]

19. Scott, H.S.; Staniland, R.W.; Kruger, P.E. Spin-crossover in Homoleptic Fe(II) Imidazolylimine Complexes. Coord. Chem. Rev. 2018, 362, 24-43. [CrossRef]

20. Kumar, K.S.; Bayeh, Y.; Gebretsadik, T.; Elemo, F.; Gebrezgiabher, M.; Thomas, M.; Ruben, M. Spin-Crossover in Iron(II)-Schiff Base Complexes. Dalton Trans. 2019, 48, 15321-15337. [CrossRef]

21. Sorai, M. Heat Capacity Studies of Spin-crossover Systems. Top. Curr. Chem. 2004, 235, 153-170.

22. Halcrow, M.A. The Foundation of Modern Spin-Crossover. Chem. Commun. 2013, 49, 10890-10892. [CrossRef]

23. Ksenofontov, V.; Gaspar, A.B.; Gutlich, P. Pressure Effect Studies on Spin-crossover and Valence Tautomeric Systems. Top. Curr. Chem. 2004, 235, 23-64.

24. Bousseksou, A.; Varret, F.; Goiran, M.; Boukheddaden, K.; Tuchagues, J.P. The Spin-crossover Phenomenon Under High Magnetic Field. Top. Curr. Chem. 2004, 235, 65-84.

25. Kamebuchi, H.; Nakamoto, A.; Yokoyama, T.; Kojima, N. Fastener Effect on Uniaxial Chemical Pressure for One-dimensional Spin-crossover System, Magnetostructural Correlation and Ligand Field analysis. Bull. Chem. Soc. Jpn. 2015, 88, 419-430. [CrossRef]

26. Hauser, A. Light-induced Spin-crossover and the High-spin to Low-spin Relaxation. Top. Curr. Chem. 2004, 234, 155-198.

27. Hauser, A.; Reber, C. Spectroscopy and Chemical Bonding in Transition Metal Complexes. Struct. Bond. 2017, 172, 291-312.

28. Bousseksou, A.; Molnar, G.; Matouzenko, G. Switching of Molecular Spin States in Inorganic Complexes by Temperature, Pressure, Magnetic Field and Light: Towards Molecular Devices. Eur. J. Inorg. Chem. 2004, 2004, 4353-4369. [CrossRef]

29. Mikolasek, M.; Félix, G.; Nicolazzi, W.; Molnar, G.; Salmon, L.; Bousseksou, A. Finite Size Effects in Molecular Spin-crossover Materials. New J. Chem. 2014, 38, 1834-1839. [CrossRef]

30. Kumar, K.S.; Ruben, M. Emerging Trends in Spin-crossover (SCO) Based Functional Materials and Devices. Coord. Chem. Rev. 2017, 346, 176-205. [CrossRef]

31. Hauser, A. Ligand Field Theoretical Considerations. Top. Curr. Chem. 2004, 233, 49-58.

32. Schaffer, C.E.; Jorgensen, C.K. The Nephelauxetic Series of Ligands Corresponding to Increasing Tendency of Partly Covalent Bonding. J. Inorg. Nuclear Chem. 1958, 8, 143-148. [CrossRef]

33. Phan, H.; Hrudka, J.J.; Igimbayeva, D.; Daku, L.M.L.; Shatruk, M. A Simple Approach for Predicting the Spin State of Homoleptic Fe(II) Tris-diimine Complexes. J. Am. Chem. Soc. 2017, 139, 6437-6447. [CrossRef]

34. Olguin, J.; Brooker, S. Spin-crossover Active Iron(II) Complexes of Selected Pyrazole-Pyridine/Pyrazine Ligands. Coord. Chem. Rev. 2011, 255, 203-240. [CrossRef]

35. Lathion, T.; Guénée, L.; Besnard, C.; Bousseksou, A.; Piguet, C. Deciphering the Influence of Meridional versus Facial Isomers in Spin-crossover Complexes. Chem. Eur. J. 2018, 24, 16873-16888. [CrossRef] [PubMed]

36. Lathion, T.; Furstenberg, A.; Besnard, C.; Hauser, A.; Bousseksou, A.; Piguet, C. Monitoring Fe(II) Spin-State Equilibria via $\mathrm{Eu}(\mathrm{III})$ Luminescence in Molecular Complexes: Dream or Reality? Inorg. Chem. 2020, 59, 1091-1103. [CrossRef] 
37. Craig, D.C.; Goodwin, H.A.; Onggo, D. Steric Influences on the Ground-State of Iron(II) in the Tris(3,3'-Dimethyl-2,2'-Bipyridine)Iron(II) Ion. Aust. J. Chem. 1988, 41, 1157-1169. [CrossRef]

38. Onggo, D.; Hook, J.M.; Rae, A.D.; Goodwin, H.A. The Influence of Steric Effects in Substituted 2,2'-Bipyridine on the Spin State of Iron(II) in $\left[\mathrm{FeN}_{6}\right]^{2+}$ Systems. Inorg. Chim. Acta 1990, 173, 19-30. [CrossRef]

39. Goodwin, H.A.; Kucharski, E.S.; White, A.H. Crystal-Structure of Tris (2-Methyl-1,10-Phenanthroline) Iron(II) Tetraphenylborate. Aust. J. Chem. 1983, 36, 1115-1124. [CrossRef]

40. Goodwin, H.A. Spin-crossover in Iron(II) Tris(diimine) and Bis(terimine) Systems. Top. Curr. Chem. 2004, 233, 59-90.

41. Edder, C.; Piguet, C.; Bünzli, J.-C.G.; Hopfgartner, G. High-spin Iron(II) as a Semi-Transparent Partner for Tuning Europium(III) Luminescence in Heterodimetallic d-f Complexes. Chem. Eur. J. 2001, 7, 3014-3024. [CrossRef]

42. Dunitz, J.D. Are Crystal Structures Predictable? Chem. Commun. 2003, 545-548. [CrossRef]

43. Dunitz, J.D.; Gavezzotti, A. How Molecules Stick Together in Organic Crystals: Weak Intermolecular Interactions. Chem. Soc. Rev. 2009, 38, 2622-2633. [CrossRef]

44. Meng, Y.S.; Liu, T. Manipulating Spin Transition to Achieve Switchable Multifunctions. Acc. Chem. Res. 2019, 52, 1369-1379. [CrossRef]

45. Kahn, O.; Martinez, C.J. Spin-transition Polymers: From Molecular Materials toward Memory Devices. Science 1998, 279, 44-48. [CrossRef]

46. Wolsey, W.C. Perchlorate Salts, Their Uses and Alternatives. J. Chem. Educ. 1973, 50, A335-A337. [CrossRef]

47. Pascal, J.-L.; Favier, F. Inorganic perchlorato complexes. Coord. Chem. Rev. 1998, 178, 865-902. [CrossRef]

48. Malinowski, E.R.; Howery, D.G. Factor Analysis in Chemistry; Wiley: New York, NY, USA, 1980.

49. Gampp, H.; Maeder, M.; Meyer, C.J.; Zuberbuehler, A.D. Calculation of Equilibrium Constants from Multiwavelength Spectroscopic Data-IV. Model-free Least-Squares Refinement by Use of Evolving Factor Analysis. Talanta 1986, 33, 943-951. [PubMed]

50. Hall, B.R.; Manck, L.E.; Tidmarsh, I.S.; Stephenson, A.; Taylor, B.F.; Blaikie, E.J.; Vander Griend, D.A.; Ward, M.D. Structures, Host-Guest Chemistry and Mechanism of Stepwise Self-Assembly of $\mathrm{M}_{4} \mathrm{~L}_{6}$ Tetrahedral Cage Complexes. Dalton Trans. 2011, 40, 12132-12145. [CrossRef]

51. Gampp, H.; Maeder, M.; Meyer, C.J.; Zuberbuehler, A.D. Calculation of Equilibrium Constants from Multiwavelength Spectroscopic Data. III. Model-free Analysis of Spectrophotometric and ESR Titrations. Talanta 1985, 32, 1133-1139. [CrossRef]

52. Maeder, M.; King, P. Analysis of Chemical Processes, Determination of the Reaction Mechanism and Fitting of Equilibrium and Rate Constants. In Chemometrics in Practical Applications; Varmuza, K., Ed.; Intech: Rigeka, Croatia, 2012.

53. ReactLab ${ }^{T M}$ Equilibria (previously Specfit/32); Jplus Consulting Pty. Ltd.: Palmyra, WA, Australia; Available online: https://jplusconsulting.com/products/reactlab-equilibria/ (accessed on 1 April 2020).

54. Bain, G.A.; Berry, J.F. Diamagnetic Corrections and Pascal's Constants. J. Chem. Educ. 2008, 85, 532-536. [CrossRef]

55. Burla, M.C.; Camalli, M.; Carrozzini, B.; Cascarano, G.L.; Giacovazzo, C.; Polidori, G.; Spagna, R. SIR99, A program for the Automatic Solution of Small and Large Crystal Structures. Acta Cryst. A 1999, 55, 991-999. [CrossRef]

56. Sheldrick, G.M. A Short History of SHELX. Acta Cryst. A 2008, 64, 112-122. [CrossRef]

57. Sheldrick, G.M. SHELXT-Integrated Space-Group and Crystal-Structure Determination. Acta Cryst. A 2015, 71, 3-8. [CrossRef]

58. Sheldrick, G.M. Crystal Structure Refinement with SHELXL. Acta Cryst. C 2015, 71, 3-8. [CrossRef] [PubMed]

59. Piguet, C.; Bocquet, B.; Hopfgartner, G. Syntheses of Segmental Heteroleptic Ligands for the Self-assembly of Heteronuclear Helical Supramolecular Complexes. Helv. Chim. Acta 1994, 77, 931-942. [CrossRef]

60. Aboshyan-Sorgho, L.; Lathion, T.; Guénée, L.; Besnard, C.; Piguet, C. Thermodynamic N-donor Trans Influence in Labile Pseudo-Octahedral Zinc Complexes: A Delusion? Inorg. Chem. 2014, 53, 13093-13104. [CrossRef] [PubMed]

61. Allinger, N.L. Conformational-Analysis.130. MM2-Hydrocarbon Force-Field Utilizing V1 and V2 Torsional Terms. J. Am. Chem. Soc. 1977, 99, 8127-8134.

62. Llunell, M.; Casanova, D.; Cirera, J.; Alemany, P.; Alvarez, S. SHAPE Is a Free Software. Available online: http://www.ee.ub.edu/ (accessed on 1 April 2020). 
63. Pinsky, M.; Avnir, D. Continuous Symmetry Measures. 5. The Classical Polyhedra. Inorg. Chem. 1998, 37, 5575-5582. [CrossRef] [PubMed]

64. Alvarez, S.; Avnir, D.; Llunell, M.; Pinsky, M. Continuous Symmetry Maps and Shape Classification. The Case of Six-Coordinated Metal Compounds. New J. Chem. 2002, 26, 996-1009. [CrossRef]

65. Casanova, D.; Cirera, J.; Llunell, M.; Alemany, P.; Avnir, D.; Alvarez, S. Minimal Distortion Pathways in Polyhedral Rearrangements. J. Am. Chem. Soc. 2004, 126, 1755-1763. [CrossRef]

66. Cirera, J.; Ruiz, E.; Alvarez, S. Shape and Spin State in Four-Coordinate Transition-Metal Complexes: The case of the d(6) Configuration. Chem. Eur. J. 2006, 12, 3162-3167. [CrossRef]

67. CRC. Handbook of Chemistry and Physics, Internet Version 2005; Lide, D.R., Ed.; CRC Press: Boca Raton, FL, USA, 2005.

68. Shannon, R.D. Revised Effective Ionic-Radii and Systematic Studies of Interatomic Distances in Halides and Chalcogenides. Acta Cryst. 1976, 32, 751-767. [CrossRef]

69. Figgis, B.N. Magnetic Properties of Spin-Free Transition Series Complexes. Nature 1958, 182, $1568-1570$. [CrossRef]

70. Martin, L.L.; Martin, R.L.; Murray, K.S.; Sargeson, A.M. Magnetism and Electronic-Structure of a Series of Encapsulated 1st-Row Transition-Metals. Inorg. Chem. 1990, 29, 1387-1394. [CrossRef]

71. Sharp, R.; Lohr, L.; Miller, J. Paramagnetic NMR Relaxation Enhancement: Recent Advances in Theory. Prog. Nucl. Magn. Reson. Spec. 2001, 38, 115-158. [CrossRef]

72. Costes, J.-P.; Clemente-Juan, J.M.; Dahan, F.; Dumestre, F.; Tuchagues, J.-P. Dinuclear (Fe(II), Gd(III)) Complexes Deriving from Hexadentate Schiff Bases: Synthesis, Structure, and Mössbauer and Magnetic Properties. Inorg. Chem. 2002, 41, 2886-2891. [CrossRef] [PubMed]

73. Boca, R. Zero-field Splitting in Metal Complexes. Coord. Chem. Rev. 2004, 248, 757-815. [CrossRef]

74. Lever, A.B.P. Inorganic Electronic Spectroscopy; Elsevier: Amsterdam, The Netherlands, 1984; pp. $126-127$.

75. Triest, N.; Bussiere, G.; Belisle, H.; Reber, C. Why Does the Middle Band in the Absorption Spectrum of $\left[\mathrm{Ni}\left(\mathrm{H}_{2} \mathrm{O}\right)_{6}\right]^{2+}$ Have Two Maxima? J. Chem. Educ. 2000, 77, 670. [CrossRef]

76. Hart, S.M.; Boeyens, J.C.A.; Hancock, R.D. Mixing of States and the Determination of Ligand Field Parameters for High-Spin Octahedral Complexes of Nickel(II). Electronic Spectrum and Structure of Bis(1,7-diaza-4-thiaheptane)nickel(II) Perchlorate. Inorg. Chem. 1983, 22, 982-986. [CrossRef]

77. Figgis, B.N.; Hitchman, M.A. Ligand Field Theory and its Application; Wiley-VCH: New York, NY, USA, 2000.

78. Robinson, M.A.; Busch, D.H.; Curry, J.D. Complexes Derived from Strong Field Ligands. 17. Electronic Spectra of Octahedral Nickel(II) Complexes with Ligands of $\alpha$-Diimine and Closley Related Classes. Inorg. Chem. 1963, 2, 1178-1181. [CrossRef]

79. Nakamoto, K. Ultraviolet Spectra and Structures of 2,2'-Bipyridine and $2,2^{\prime}, 2^{\prime \prime}$-Terpyridine in Aqueous Solution. J. Phys. Chem. 1960, 64, 1420-1425. [CrossRef]

80. Xu, S.; Smith, J.E.T.; Weber, J.M. UV Spectra of Tris(2,2'-bipyridine)-M(II) Complex Ions in Vacuo (M = Mn, $\mathrm{Fe}, \mathrm{Co}, \mathrm{Ni}, \mathrm{Cu}, \mathrm{Zn})$. Inorg. Chem. 2016, 55, 11937-11943. [CrossRef]

81. Alderighi, L.; Gans, P.; Ienco, A.; Peters, D.; Sabatini, A.; Vacca, A. Hyperquad Simulation and Speciation (HySS): A Utility Program for the Investigation of Equilibria Involving Soluble and Partially Soluble Species. Coord. Chem. Rev. 1999, 184, 311-318. [CrossRef]

82. Borkovec, M.; Hamacek, J.; Piguet, C. Statistical Mechanical Approach to Competitive Binding of Metal Ions to Multi-center Receptors. Dalton Trans. 2004, 4096-4105. [CrossRef] [PubMed]

83. Piguet, C. Five Thermodynamic Describers for Addressing Serendipity in the Self-assembly of Polynuclear Complexes in Solution. Chem. Commun. 2010, 46, 6209-6231. [CrossRef] [PubMed]

84. Benson, S.W. Statistical Factors in the Correlation of Rate Constants and Equilibrium Constants. J. Am. Chem. Soc. 1958, 80, 5151-5154. [CrossRef]

85. Ercolani, G.; Piguet, C.; Borkovec, M.; Hamacek, J. Symmetry Numbers and Statistical Factors in Self-assembly and Multivalency. J. Phys. Chem. B 2007, 111, 12195-12203. [CrossRef] [PubMed]

86. Ercolani, G.; Schiaffino, L. Allosteric, Chelate, and Intermolecular Cooperativity: A Mise au Point. Angew. Chem. Int. Ed. 2011, 50, 1762-1768. [CrossRef] [PubMed]

(C) 2020 by the authors. Licensee MDPI, Basel, Switzerland. This article is an open access article distributed under the terms and conditions of the Creative Commons Attribution (CC BY) license (http://creativecommons.org/licenses/by/4.0/). 